\title{
Dematerialization Through Services: Evaluating the Evidence
}

\author{
Blair Fix*
}

February 13, 2019

\begin{abstract}
Dematerialization through services is a popular proposal for reducing environmental impact. The idea is that by shifting from the production of goods to the provision of services, a society can reduce its material demands. But do societies with a larger service sector actually dematerialize? I test the 'dematerialization through services' hypothesis with a focus on fossil fuel consumption and carbon emissions - the primary drivers of climate change. I find no evidence that a service transition leads to carbon dematerialization. Instead, a larger service sector is associated with greater use of fossil fuels and greater carbon emissions per person. This suggests that 'dematerialization through services' is not a valid sustainability policy.
\end{abstract}

*Author contact: blairfix@gmail.com 


\section{Introduction}

'Dematerialization through services' (Heiskanen and Jalas, 2000) is a popular proposal for reducing environmental impact. The idea is that by shifting from producing goods to providing services, a society can reduce its use of materials. But do societies with a larger service sector actually dematerialize? I test the 'dematerialization through services' hypothesis with a focus on fossil fuel use and carbon emissions - the primary drivers of climate change. I ask: does a service transition lead to fossil fuel and/or carbon emissions dematerialization?

Using international data from the World Bank, I test for both relative and absolute carbon dematerialization through services. Over the long term, I find that a service transition leads to an increase in the carbon intensity of GDP. Similarly, I find that a service transition leads to increasing carbon emissions per capita. This finding echos Jevons' paradox. Jevons (1906) found that the adoption of more energy efficient technology led to greater (not lesser) energy use (Alcott, 2005; Polimeni et al, 2012). Like more efficient technology, the service sector can supposedly do more with less. It generates more value added per unit of direct energy input. Yet a service transition produces the opposite of its intended effect. The relative growth of the service sector is associated with greater energy use (and hence greater emissions). The reasons why this occurs are likely complex, but the implications are simple. The evidence indicates that 'dematerialization through services' is not a valid sustainability policy.

This paper is laid out as follows. Section 2 discusses the rationale behind the 'dematerialization through services' proposal. Section 3 outlines methods and Section 4 discusses results. Section 5 discusses reasons why the 'dematerialization through services' proposal fails. Section 6 concludes with thoughts on the significance of this evidence, and what it means for sustainability policy.

\section{Dematerialization Through Services: The Rationale}

The 'dematerialization through services' proposal begins with an uncontentious observation. In terms of direct energy use, the service sector is less energy intensive than industrial sectors like mining, manufacturing, and construction. For instance, the US service sector is about 3 to 4 times less energy intensive than US industry (Fig. 1).

Proponents of the 'dematerialization through services' hypothesis take this uncontentious observation, and go one step further. Because of the lower direct resource intensity of the service sector, they propose that a "transition from an 
A. Direct Energy Intensity of Value Added

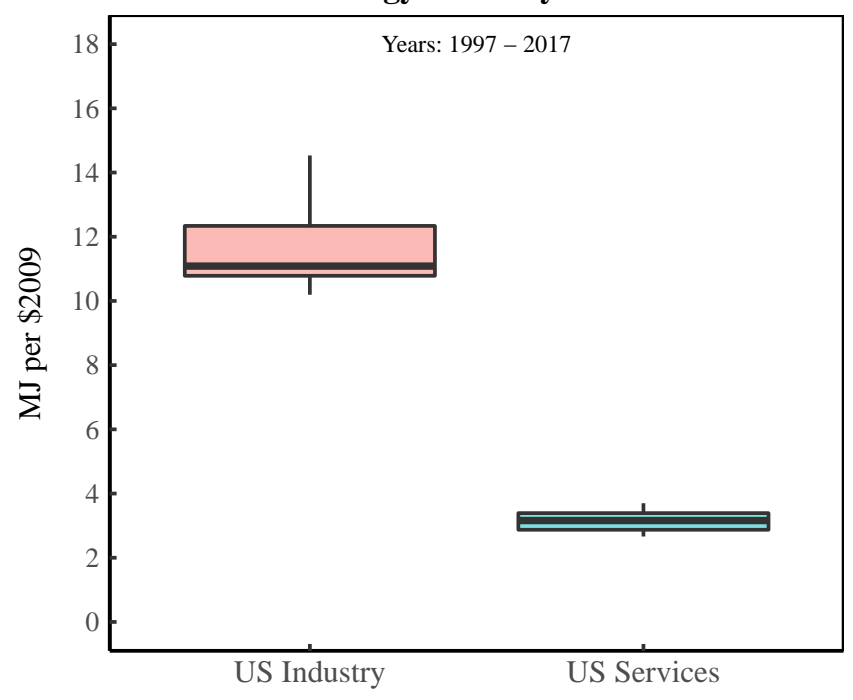

B. Direct Energy Use per Worker

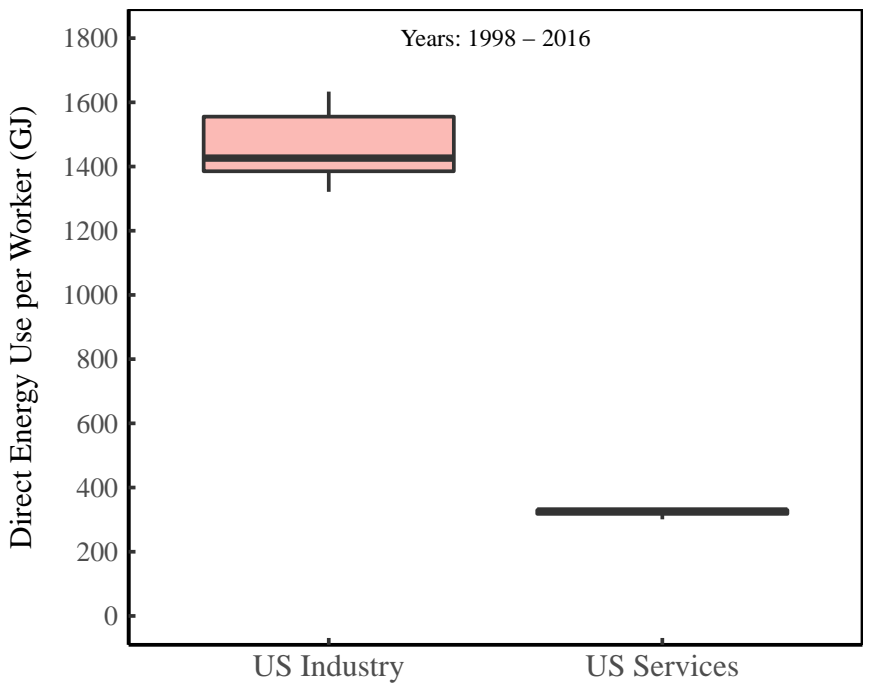

Figure 1: Comparing the Direct Energy Intensity of US Sectors

This figure compares the direct energy intensity of US industry and US services. 'Industry' consists of mining, manufacturing, construction and utilities. 'Services' consist of all other non-industrial sectors (except agriculture). Panel A shows the energy intensity of value added for US industry and US services over the years 1997 to 2017. Panel B shows energy use per worker for US industry and US services over the years 1998 to 2016. For sources and methods, see the Appendix.

industrial to a service society might bring about a decline in the use of materials" (Herman et al, 1990). A non-exhaustive list of authors who have echoed this proposal would include Cooper (1999), Hawken (2000), Herman et al (1990), Hinterberger and Schmidt-Bleek (1999), Jackson (1996), Kahn (1979), Lovins et al (1999), OECD (2000), Panayotou et al (2000), Romm et al (1999), Romm (2002), Stahel (1997), Victor (2010), and White et al (1999). For a good review of the literature on this topic, see Heiskanen and Jalas (2000) and Heiskanen et al (2001).

While based on plausible reasoning, the 'dematerialization through services' proposal has many critics. Djellal and Gallouj (2016), Jespersen (1999), and Lawn (2001) have all argued that it is wrong to treat the service sector as a separate entity from industry. Instead, they argue that services are intrinsically connected to the production of goods (and vice versa). For instance, a car dealership (a service) depends on the production of cars for its existence. Likewise, the car manufacturer depends on the dealership to sell its product. The service sector cannot and does not operate in isolation (Giampietro et al, 2012; Hall 
and Klitgaard, 2012). One way to capture this interdependence is to measure both direct and indirect energy use. Jesperson (1999) finds that when indirect energy use is included, the Danish private service sector has an energy intensity similar to the manufacturing sector.

Kander (2005) identifies a more subtle problem. The growth of the service sector's share of value added is affected by price change. The problem is that service sector prices tend to rise faster than the price of goods. This means that using 'nominal' prices can inflate the growth of the service sector. When 'real' prices are used, there is less evidence for dematerialization through services (Henriques and Kander, 2010).

Another problem, is that the transition to services could increase transport volumes (Ellger and Scheiner, 1997). Amazon.com's business model is a good example. Greater transportation volume could nullify any dematerialization that might otherwise occur.

There is also the problem of open borders. Western countries that are deindustrializing are not doing so in isolation. Instead, they are off-shoring many of their industrial processes to developing countries. Davis and Caldeira (2010) find that the US and Western Europe have significant net CO2 emissions embodied in trade. Similarly, Knight and Schor (2014) find that evidence for emissionsGDP decoupling disappears when they account for the emissions embodied in trade. This means we should be skeptical of dematerialization claims that do not account for trade effects (Stern et al, 1996; Day et al, 2014).

But perhaps the most damning critique of 'dematerialization through services' is that its proponents focus on relative rather than absolute dematerialization. Proponents tout the decreasing energy intensity of GDP. But this is a relative (i.e. intensive) metric that does not indicate the scale of energy use (Giampietro et al, 2012). Our impact on the biosphere depends on the scale of consumption, not the efficiency of this consumption (Ehrlich and Holdren, 1971).

Giampietro et al. (2012) use the analogy of a mouse and an elephant to illustrate this point. A mouse has a metabolic rate of about $3 \mathrm{~W} / \mathrm{kg}$, while an elephant has a metabolic rate of about $0.5 \mathrm{~W} / \mathrm{kg}$. Clearly the elephant is more efficient at using energy. However, the elephant's total energy demand is about 50,000 times that of the mouse. Despite its greater efficiency, the elephant has a far greater impact on its environment. Likewise a wealthy nation may generate more value added per unit of energy than a developing nation. But if the wealthy nation uses more non-renewable energy than the developing nation, its greater 'efficiency' is a moot point for sustainability purposes. Giampietro et al. do not mince words: 
That modern neoclassical economists (and quite a few ecological economists) see elephants as dematerialized versions of mice would be a mere amusing finding, if it were not for the fact that this silly narrative is being taught to students in almost every academic programme dealing with the sustainability of human progress ... (Giampietro et al, 2012)

Similar critiques have been raised by Daly (2013), Hall and Klitgaard (2012), and Jackson (2009), among others. I take this critique seriously. Thus, I test for both relative and absolute dematerialization.

\section{Methods}

To test for dematerialization through services, I focus on fossil fuel use and CO2 emissions. This gives a direct indicator of climate-change sustainability. I use four different metrics of dematerialization (Tbl. 1). I define relative dematerialization as a decline in the fossil fuel and/or carbon intensity of GDP. I define absolute carbon dematerialization as a reduction in per capita carbon emissions and fossil fuel use (not total emissions and/or fossil fuel use). I use per capita data because I compare countries that have different populations. This removes the effects of population growth, which I regard as a separate sustainability issue from the growth of per capita consumption. Service sector size is measured using both employment share and value-added share (using current prices). ${ }^{1}$

I test for a scaling relation between each dematerialization metric $(D)$ and the service fraction $\left(S_{\text {frac }}\right.$ ) of employment or value added:

$$
D \propto S_{\text {frac }}^{\alpha}
$$

Equation 1 can be rewritten in terms of a log-log regression:

$$
\log (D) \propto \alpha \cdot \log \left(S_{\text {frac }}\right)
$$

The scaling-exponent $\alpha$ quantifies how the dematerialization metric $D$ behaves

\footnotetext{
${ }^{1}$ Why not measure service sector value added using 'real' prices? First, this data is not available from the World Bank database used here. Second, there are numerous problems with price deflation. The main problem is that relative prices change over time, meaning the choice of base year will affect the resulting deflation (Fix, 2015; Nitzan, 1992; Nitzan and Bichler, 2009). Kander (2005) highlights how this affects the calculation of the service sector's share of value added. This same problem also leads to systematic uncertainty in the calculation of real GDP. However, out of convention, I use standard measures of real GDP to test for relative dematerialization. But it is important to recognize that real GDP is not necessarily an objective measure of economic output (Fix, 2019).
} 
Table 1: Metrics of Dematerialization and Service Sector Size

\begin{tabular}{ll}
\hline Absolute Dematerialization & Relative Dematerialization \\
\hline Fossil fuel use per capita & Fossil fuel intensity of GDP \\
CO2 emissions per capita & CO2 intensity of GDP \\
\hline Service Sector Size & \\
\hline Service sector share of employment \\
Service sector share of value added \\
\hline
\end{tabular}

Table 2: World Bank Data Series

\begin{tabular}{ll}
\hline Series Code & Description \\
\hline EG.EGY.PRIM.PP.KD & Energy intensity level of primary energy (MJ/\$2011 PPP GDP) \\
EG.USE.COMM.FO.ZS & Fossil fuel energy consumption (\% of total) \\
EG.USE.PCAP.KG.OE & Energy use (kg of oil equivalent per capita) \\
EN.ATM.CO2E.PC & CO2 emissions (metric tons per capita) \\
EN.ATM.CO2E.PP.GD.KD & CO2 emissions (kg per 2011 PPP \$ of GDP) \\
NV.SRV.TETC.ZS & Services, etc., value added (\% of GDP) \\
SL.AGR.EMPL.ZS & Employment in agriculture (\% of total employment) \\
SL.IND.EMPL.ZS & Employment in industry (\% of total employment) \\
SL.SRV.EMPL.ZS & Employment in services (\% of total employment) \\
SL.TLFTOTL.IN & Labor force, total \\
SP.POPTOTL & Population, total \\
\hline
\end{tabular}

as the service sector grows. A negative exponent indicates that the dematerialization metric declines as the service sector increases in size. This is evidence for dematerialization through services. A positive exponent indicates that the dematerialization metric increases as the service sector increases in size. This is evidence against dematerialization through services.

All data for this test comes from the World Bank and covers 217 countries over the years 1991 to 2017 (Tbl. 2). This data is sufficient to conduct a robust test of dematerialization trends between countries. It also allows a more limited test for trends within countries. The short (30 year) time frame limits the ability to establish statistically significant trends within countries. 
A. Fossil Fuel Use per Capita vs. Service Employment

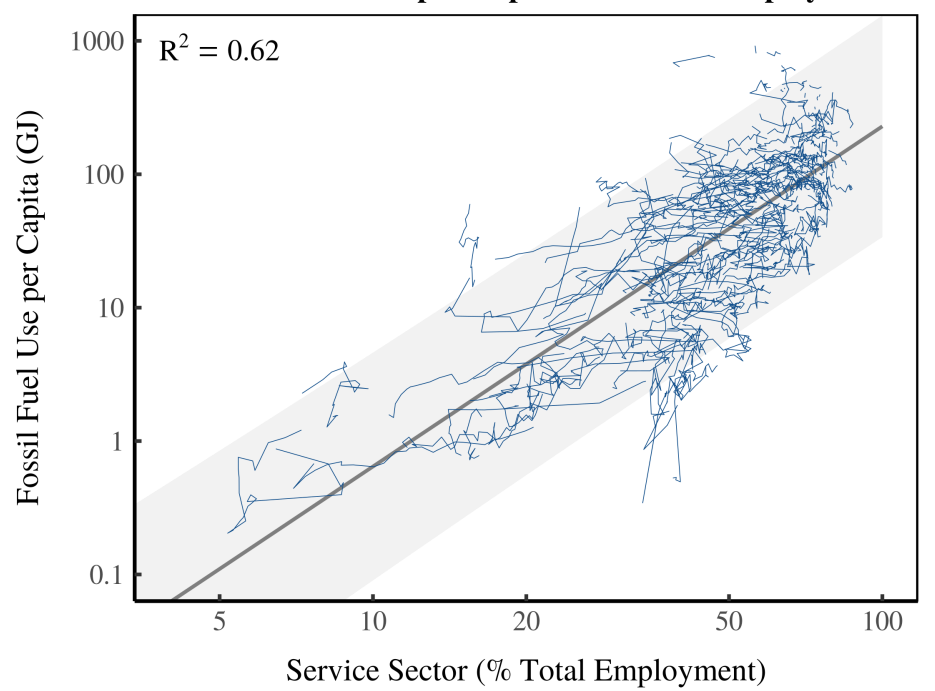

C. Fossil Fuel Use per Capita vs. Service Value Added

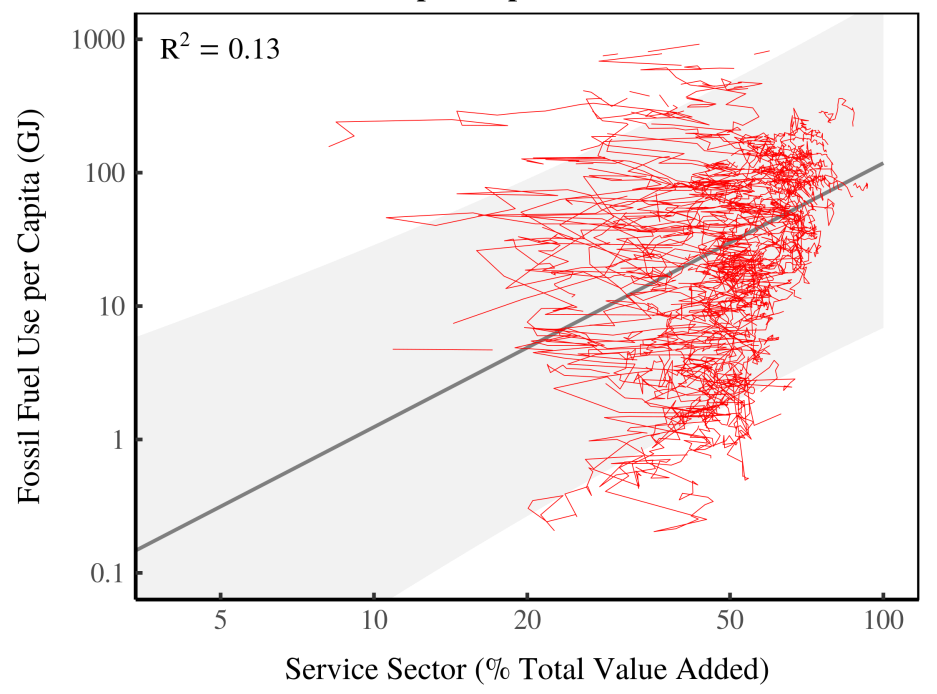

B. CO2 Emissions per Capita vs. Service Employment

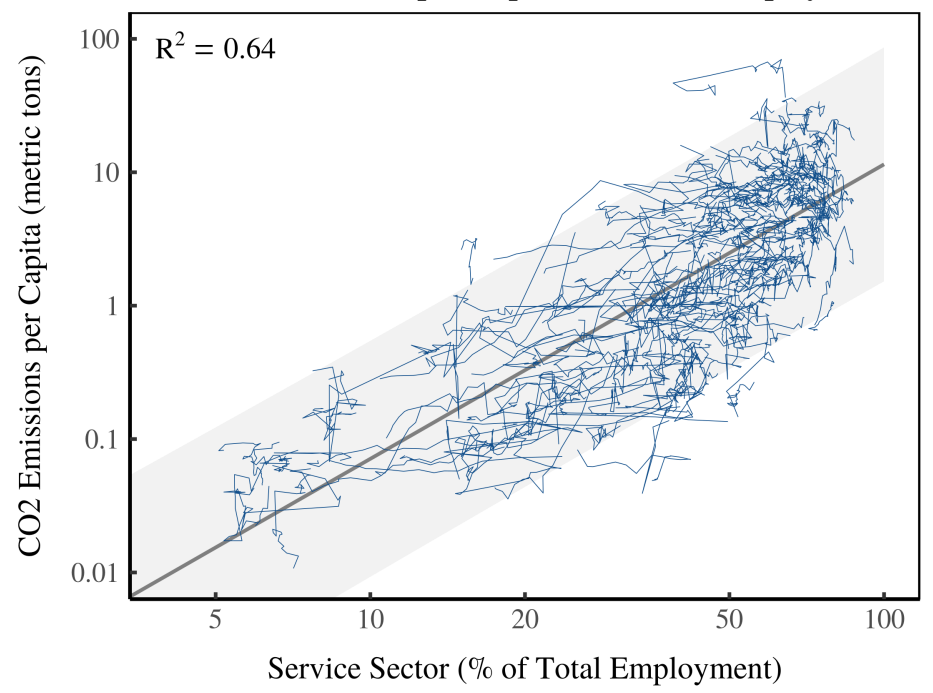

B. CO2 Emissions per Capita vs. Service Value Added

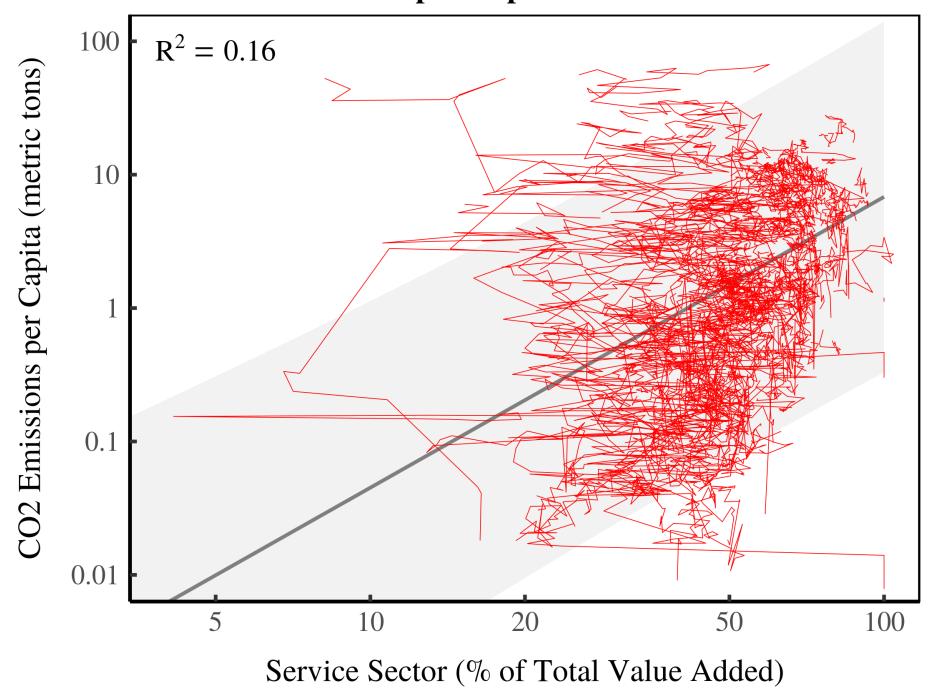

Figure 2: Testing for Absolute Carbon Dematerialization Through Services

This figure tests for absolute dematerialization through services using between-country evidence. Lines represent the path through time of countries over the years 1991 to 2017. All plots use log-log scales. $R^{2}$ values are for log-log regressions on mean values for each country. Grey regions indicate the $95 \%$ prediction interval of each regression. Panel A shows the relation between the fossil fuel intensity of GDP (measured in \$2011 purchasing power parity) and service sector employment share. Panel B shows the relation between the CO2 intensity of GDP and service sector employment share. Panels C and D keep the same $y$-axis as Panels A and B (respectively), but measure service sector size using percentage of total value added. All data comes from the World Bank (Tbl. 2). 
A. Fossil Fuel Use per Capita vs. Service Employment

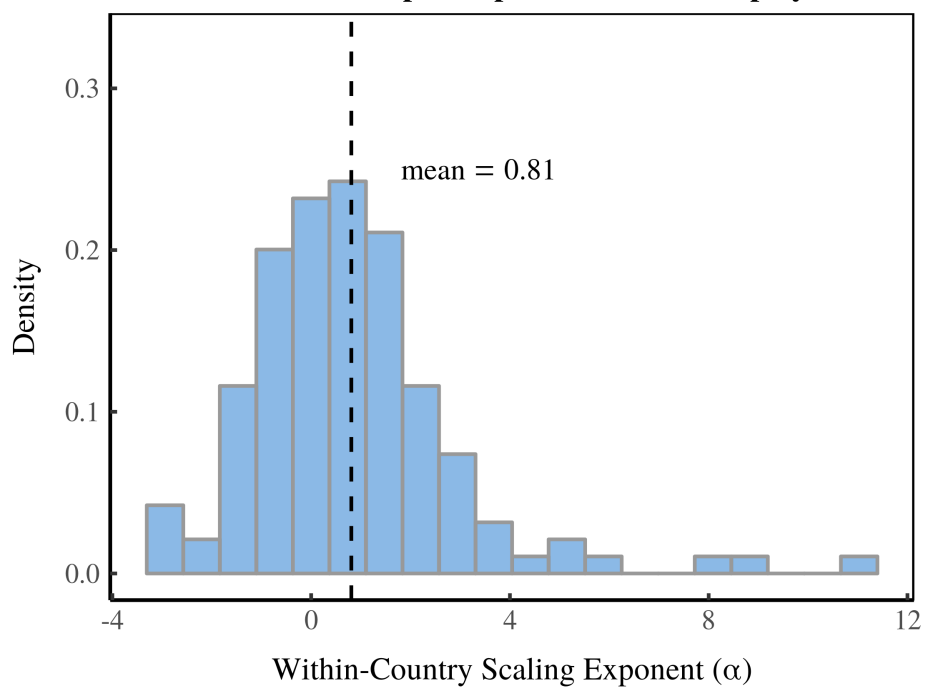

C. Fossil Fuel Use per Capita vs. Service Value Added

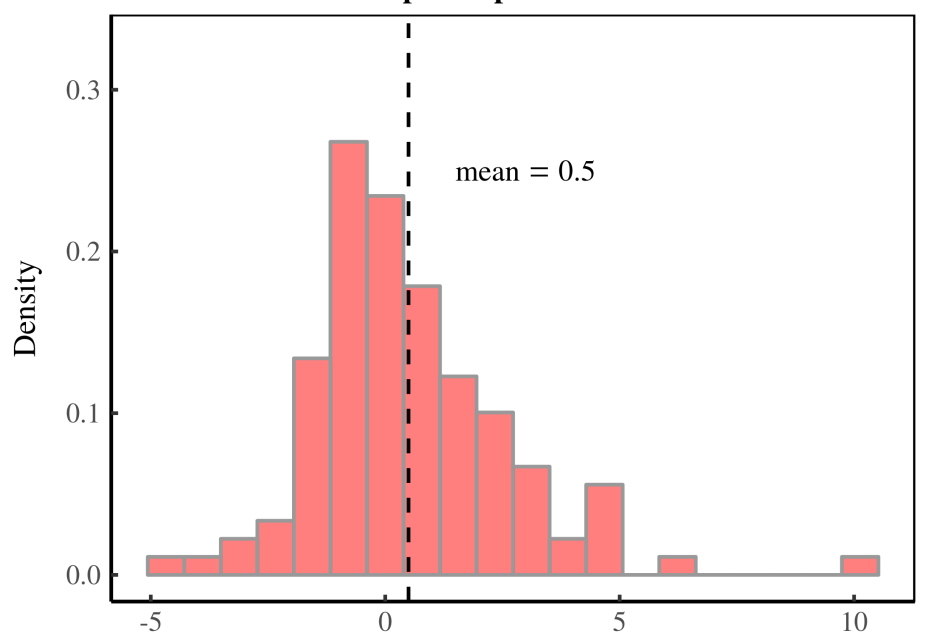

Within-Country Scaling Exponent $(\alpha)$
B. CO2 Emissions per Capita vs. Service Employment

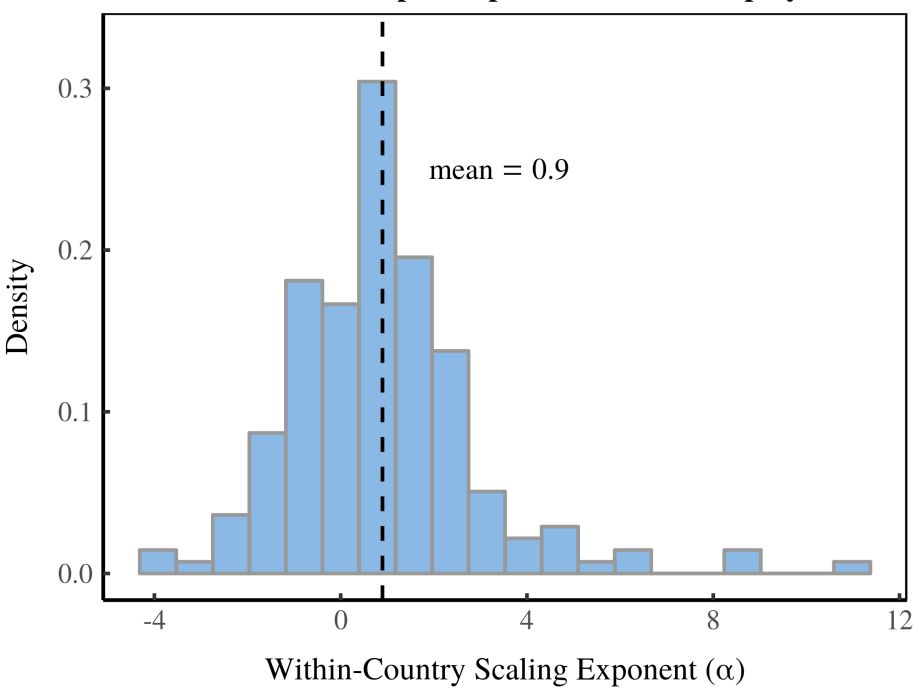

D. CO2 Emissions per Capita vs. Service Value Added

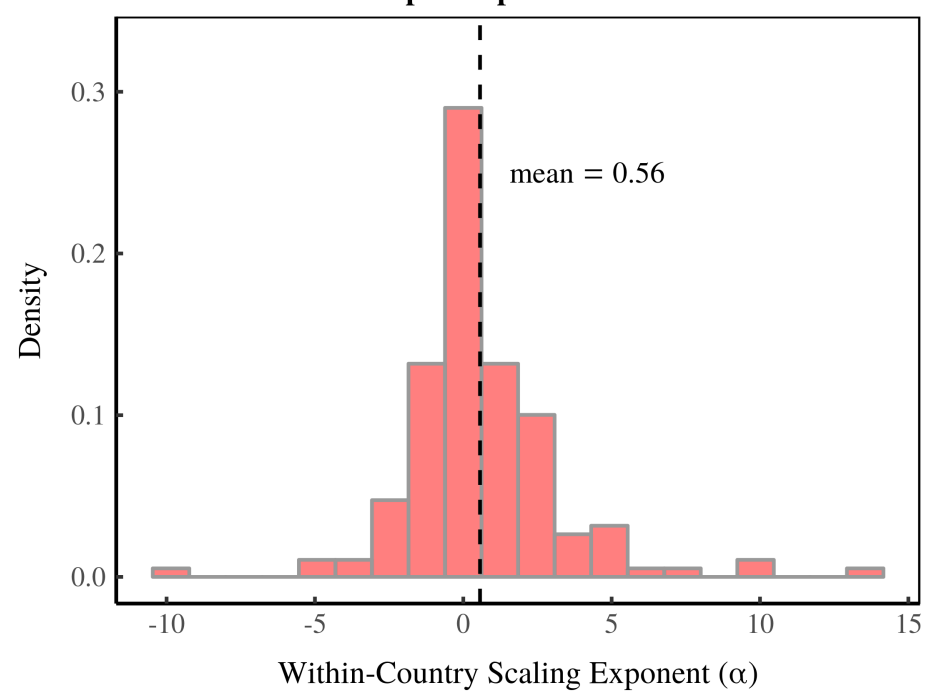

Figure 3: Relative Carbon Dematerialization Through Services - WithinCountry Evidence

This figure tests for absolute dematerialization through services using within-country evidence. Histograms show the distribution of within-country scaling exponents $\alpha$ (see Eq. 1 and Eq. 2) over the years 1991 to 2017. Vertical lines indicate the mean withincountry exponent. Panel A shows the relation between the fossil fuel intensity of GDP (measured in \$2011 purchasing power parity) and service sector employment share. Panel B shows the relation between the CO2 intensity of GDP and service sector employment share. Panels C and D are similar to panels A and B, but measure service sector size using percentage of total value added. All data comes from the World Bank (Tbl. 2). 
A. Fossil Fuel Intensity of GDP vs. Service Employment

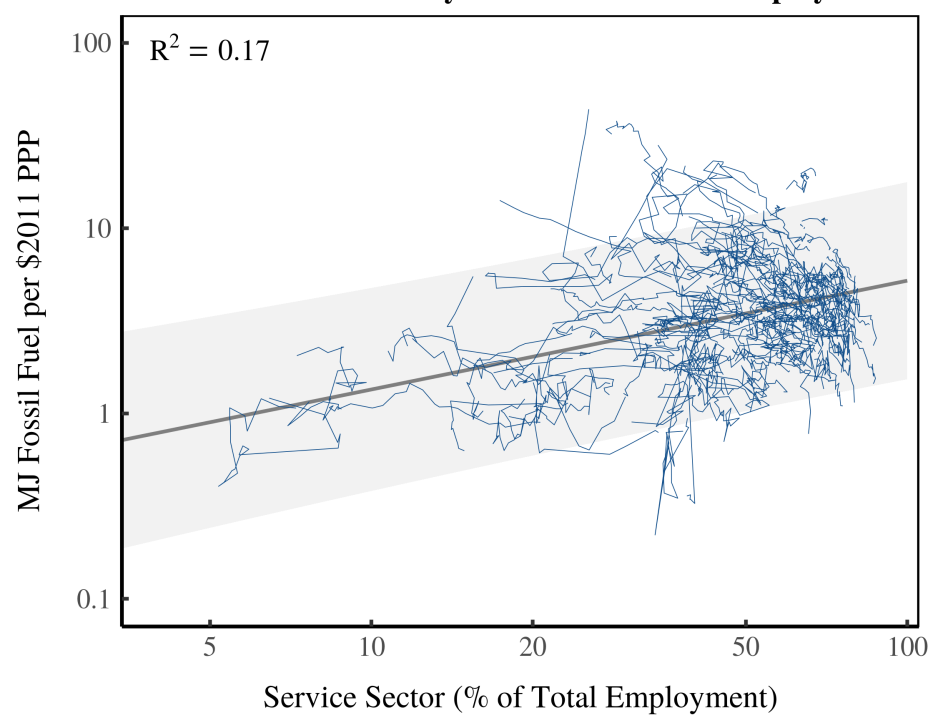

C. Fossil Fuel Intensity of GDP vs. Service Value Added

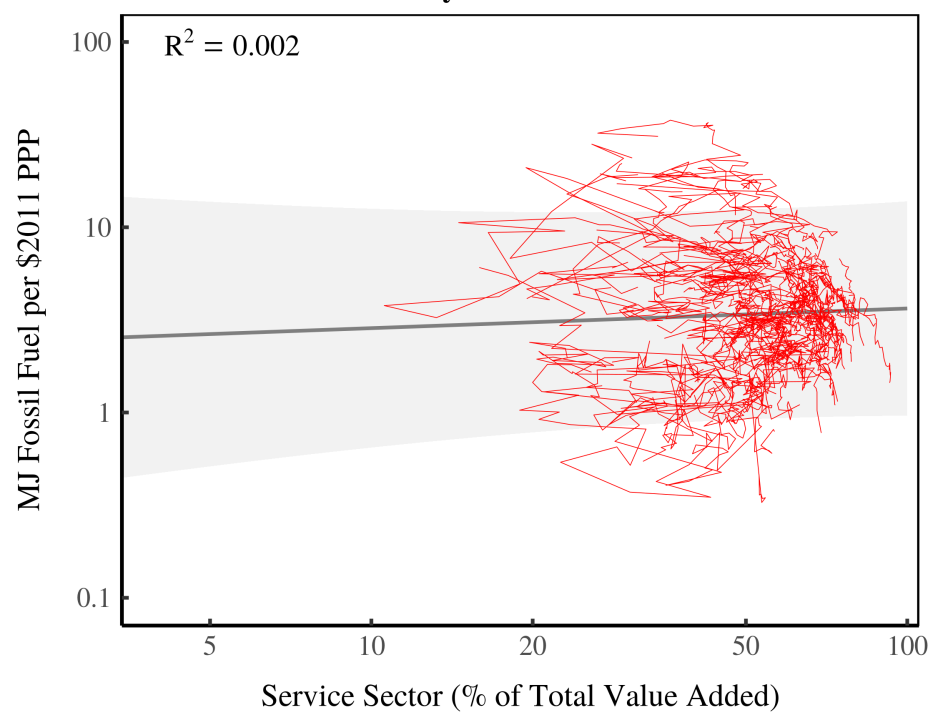

B. CO2 Intensity of GDP vs. Service Employment

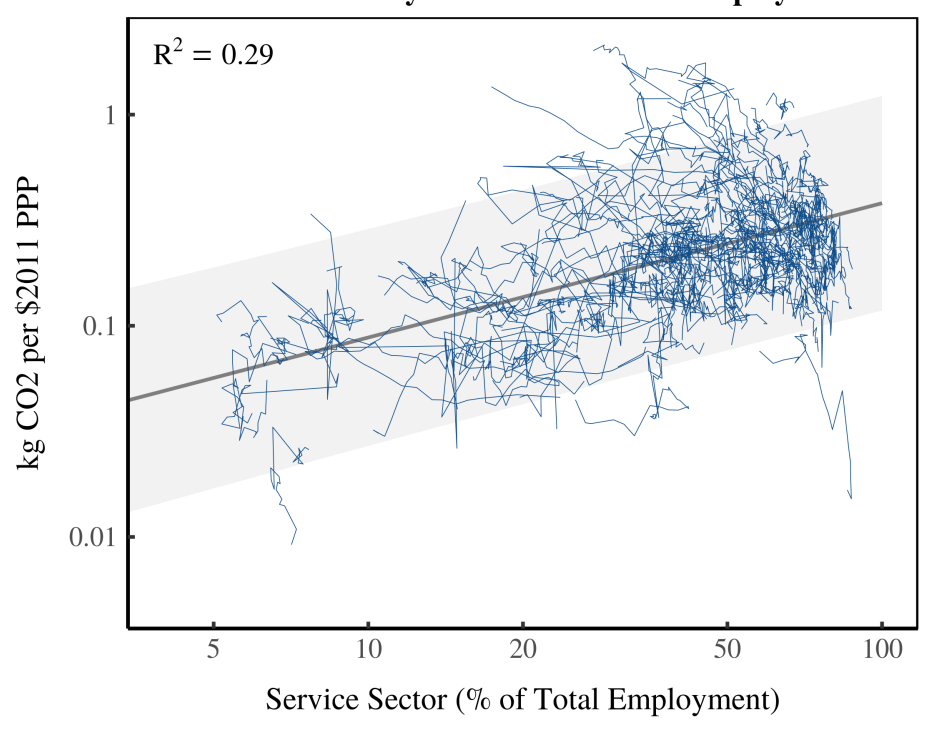

D. CO2 Intensity of GDP vs. Service Value Added

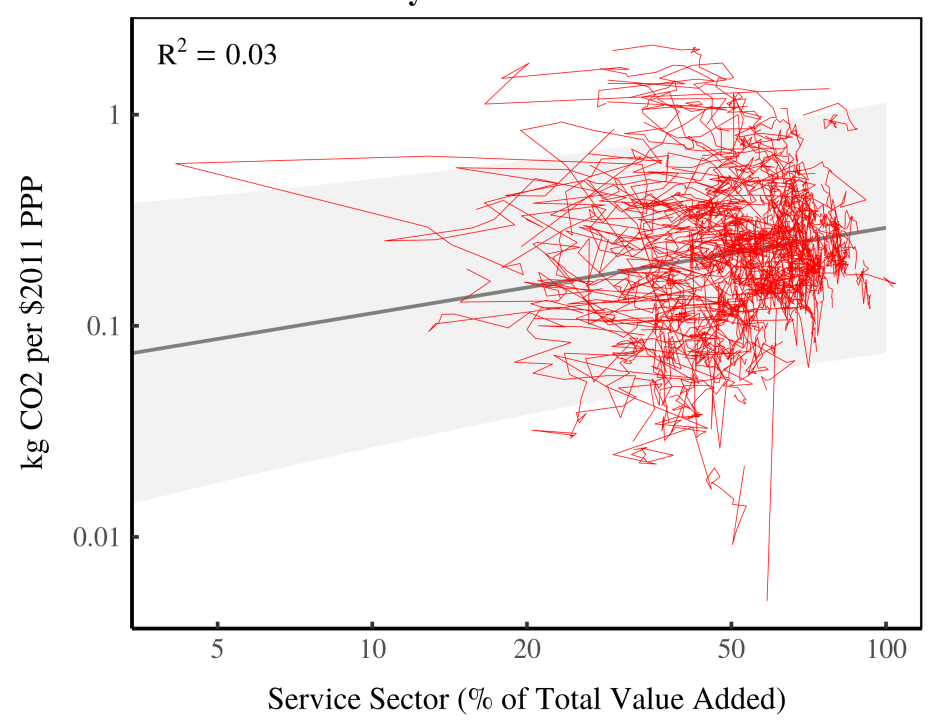

Figure 4: Relative Carbon Dematerialization Through Services - BetweenCountry Evidence

This figure tests for relative dematerialization through services using between-country evidence. Lines represent the path through time of countries over the years 1991 to 2017. All plots use log-log scales. $R^{2}$ values are for log-log regressions on mean values for each country. Grey regions indicate the $95 \%$ prediction interval of each regression. Panel A shows the relation between the fossil fuel intensity of GDP (measured in \$2011 purchasing power parity) and service sector employment share. Panel B shows the relation between the CO2 intensity of GDP and service sector employment share. Panels C and D keep the same $y$-axis as Panels A and B (respectively), but measure service sector size using percentage of total value added. All data comes from the World Bank (Tbl. 2). 
A. Fossil Fuel Intensity of GDP vs. Service Employment

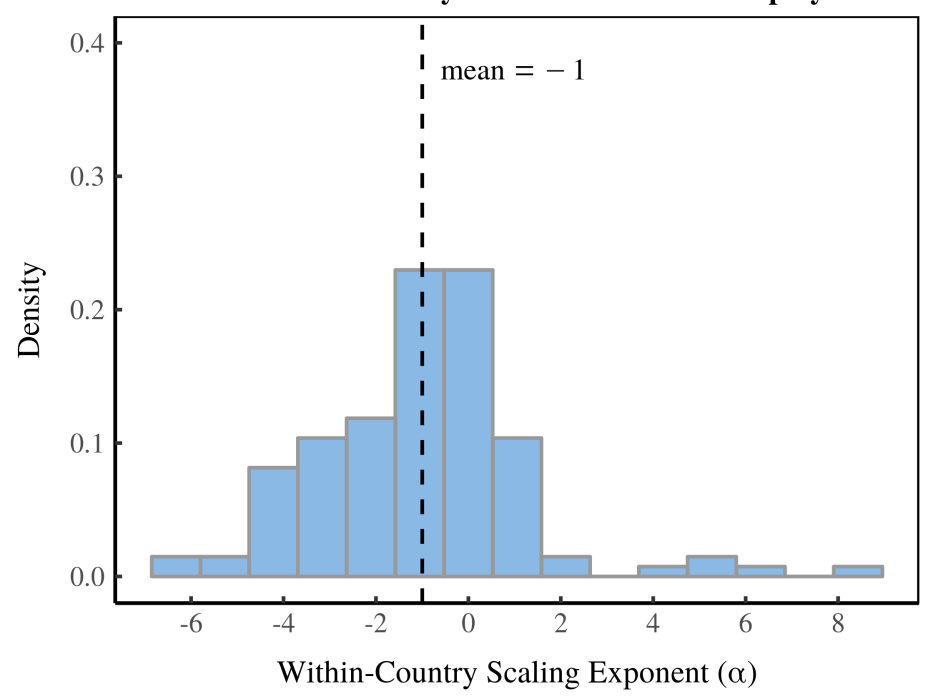

C. Fossil Fuel Intensity of GDP vs. Service Value Added

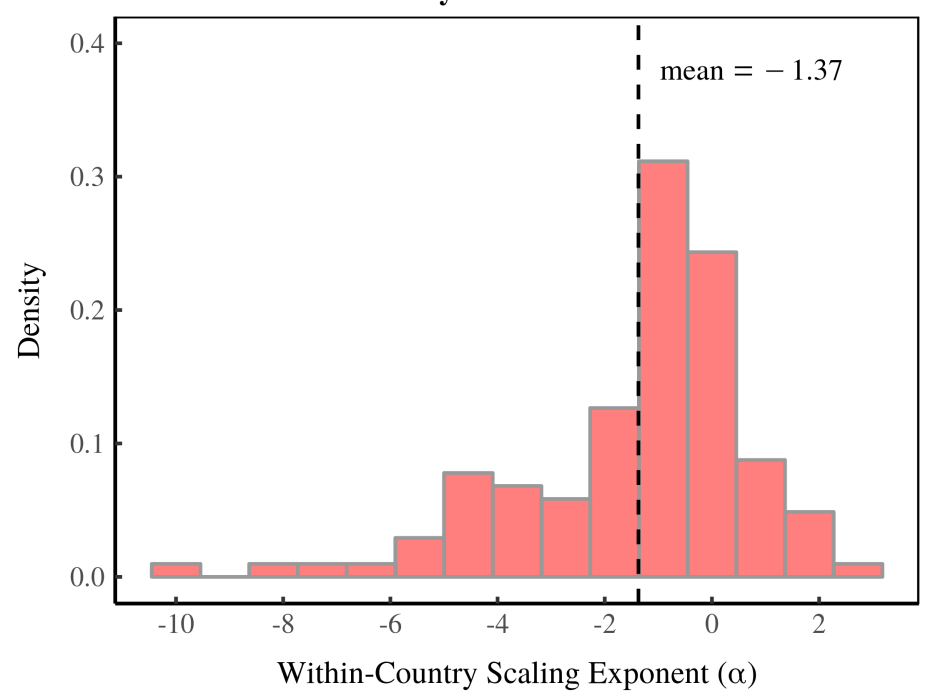

B. CO2 Intensity of GDP vs. Service Employment

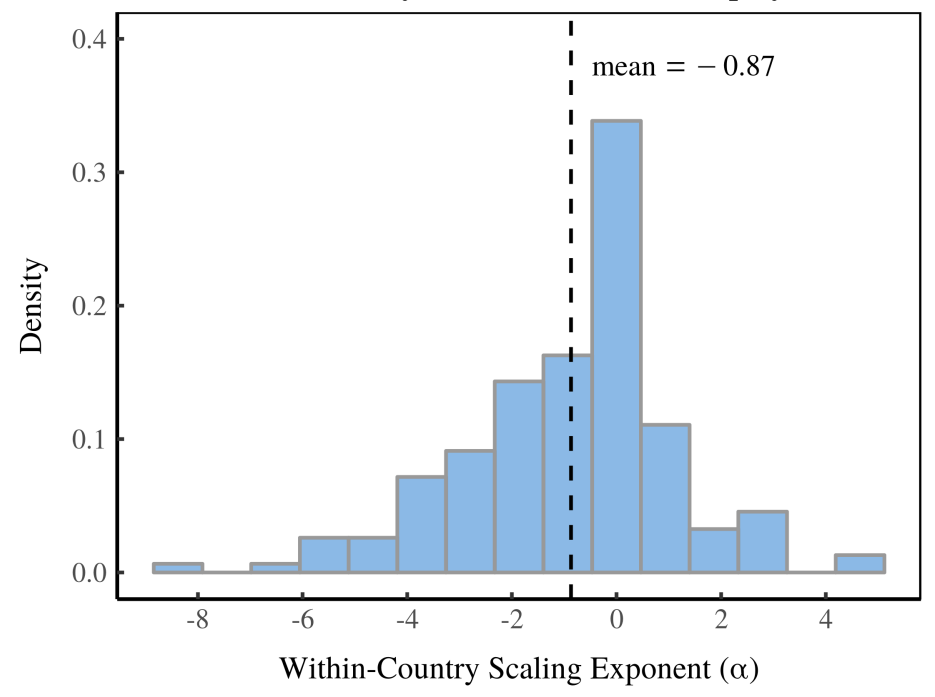

D. CO2 Intensity of GDP vs. Service Value Added

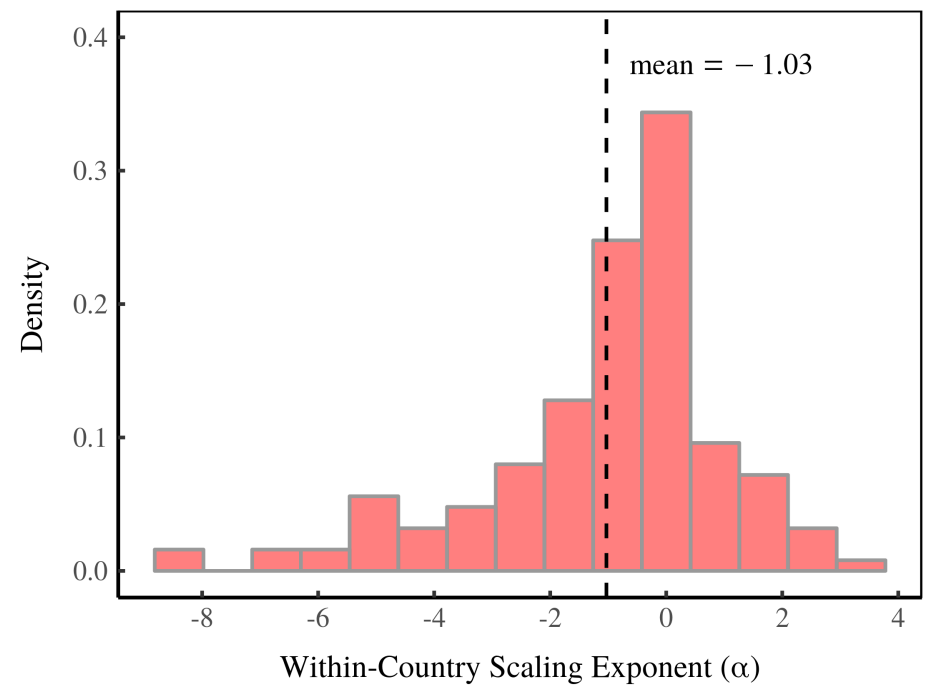

\section{Figure 5: Relative Carbon Dematerialization Through Services - Within- Country Evidence}

This figure tests for relative dematerialization through services using within-country evidence. Histograms show the distribution of within-country scaling exponents $\alpha$ (see Eq. 1 and Eq. 2) over the years 1991 to 2017. Vertical lines indicate the mean withincountry exponent. Panel A shows the relation between the fossil fuel intensity of GDP (measured in \$2011 purchasing power parity) and service sector employment share. Panel B shows the relation between the CO2 intensity of GDP and service sector employment share. Panels C and D are similar to panels A and D, but measure service sector size using percentage of total value added. All data comes from the World Bank (Tbl. 2). 
Table 3: Absolute Carbon Dematerialization - Between-Country Evidence

\begin{tabular}{lccc}
\hline Regression & $\alpha$ & $R^{2}$ & $p$ \\
\hline Fossil Fuel Use per Capita vs. Service Employment Share & 2.55 & 0.62 & $* * *$ \\
C02 Emissions per Capita vs. Service Employment Share & 2.21 & 0.64 & $* * *$ \\
Fossil Fuel Use per Capita vs. Service Value-Added Share & 1.98 & 0.13 & $* * *$ \\
C02 Emissions per Capita vs. Service Value-Added Share & 2.18 & 0.16 & $* * *$ \\
\hline
\end{tabular}

Table 4: Absolute Carbon Dematerialization — Within-Country Evidence

\begin{tabular}{lccc}
\hline Regression & $\bar{\alpha}$ & $\overline{R^{2}}$ & $\bar{p}$ \\
\hline Fossil Fuel Use per Capita vs. Service Employment Share & 0.81 & 0.41 & 0.12 \\
C02 Emissions per Capita vs. Service Employment Share & 0.90 & 0.41 & 0.13 \\
Fossil Fuel Use per Capita vs. Service Value-Added Share & 0.50 & 0.36 & 0.11 \\
C02 Emissions per Capita vs. Service Value-Added Share & 0.56 & 0.31 & 0.17 \\
\hline
\end{tabular}

Table 5: Relative Carbon Dematerialization — Between-Country Evidence

\begin{tabular}{lccc}
\hline Regression & $\alpha$ & $R^{2}$ & $p$ \\
\hline Fossil Fuel Intensity of GDP vs. Service Employment Share & 0.59 & 0.17 & $* * *$ \\
C02 Intensity of GDP vs. Service Employment Share & 0.64 & 0.29 & $* * *$ \\
Fossil Fuel Intensity of GDP vs. Service Value-Added Share & 0.11 & 0.00 & 0.62 \\
C02 Intensity of GDP vs. Service Value-Added Share & 0.40 & 0.03 & 0.02 \\
\hline
\end{tabular}

Table 6: Relative Carbon Dematerialization - Within-Country Evidence

\begin{tabular}{lccc}
\hline Regression & $\bar{\alpha}$ & $\overline{R^{2}}$ & $\bar{p}$ \\
\hline Fossil Fuel Intensity of GDP vs. Service Employment Share & -1.00 & 0.48 & 0.12 \\
C02 Intensity of GDP vs. Service Employment Share & -0.87 & 0.42 & 0.13 \\
Fossil Fuel Intensity of GDP vs. Service Value-Added Share & -1.37 & 0.41 & 0.10 \\
C02 Intensity of GDP vs. Service Value-Added Share & -1.03 & 0.35 & 0.17 \\
\hline
\end{tabular}

$R^{2}$ and $p$-values are for log-log regressions. $\alpha$ is the slope of the regression (see Eq. 1 and 2 ).

$$
* * * p<10^{-4}
$$

$\bar{\alpha}, \overline{R^{2}}$ and $\bar{p}$ indicate the average within-country regression values. 


\section{Results}

Figures $2-5$ show the results of my test for carbon dematerialization through services. Figures 2 tests for absolute dematerialization using trends between countries. Figure 3 tests for absolute dematerialization using trends within countries. Figure 4 tests for relative dematerialization using trends between countries. Lastly, Figure 5 tests for relative dematerialization using trends within countries. Results are summarized in Tables 3-6.

I find no evidence that a service transition leads to absolute carbon dematerialization. The between-country trends are clear (Fig. 2 and Tbl. 3). A service transition is systematically associated with the growth of per capita fossil fuel use and carbon emissions. Within-country trends (Fig. 3 and Tbl. 4) are also positive on average, but with a smaller scaling exponent and weaker statistical significance. This weaker evidence is likely due to the short period covered by the within-country data. This allows statistical 'noise' to dominate the 'signal'. Still, the data is sufficient to draw conclusions. There is no evidence for a negative scaling exponent (on average) either between or within countries. Thus, this test does not support absolute dematerialization through services.

The evidence for relative dematerialization through services is less clear. Between-country evidence (Fig. 4 and Tbl. 5) indicates that a service transition is associated with greater fossil fuel intensity and CO2 intensity of GDP. This relation is statistically significant when service sector size is measured using employment. It is not significant (at the $1 \%$ level) when service sector size is measured using value added. Since there is no evidence for a negative scaling exponent, the between-country data does not support relative dematerialization through services. However, the within-country evidence seems to contradict this finding (Fig. 5 and Tbl. 6). Here, the average scaling relation is negative, but with weak statistical significance. The within-country data supports relative dematerialization through services, but contradicts the between-country evidence. I discuss the reason for this apparent contradiction in Section 5.

To summarize, the evidence indicates that a service transition does not lead to absolute carbon dematerialization. Thus, we must conclude that a service transition does not lead to greater sustainability. The evidence for relative carbon dematerialization is less clear. While unimportant for sustainability, relative dematerialization is a popular concept among environmental economists. Thus, it is important to understand the cause of the contradictory evidence. 


\section{Discussion}

Our test of dematerialization through services yielded two notable findings. First, the evidence for relative dematerialization was conflicting. Second, there was no evidence for absolute dematerialization through services. I discuss possible explanations for these findings below.

\subsection{The Contradictory Evidence for Relative Carbon Dematerializa- tion}

Why does between-country evidence suggest that relative carbon dematerialization through services is a failure? Yet within-country evidence suggests that it is a success? The answer is that relative carbon dematerialization trends are likely non-linear. They have an inverted-U shape over the long term.

To understand this behavior, we begin with the following relation:

$$
\frac{E_{F F}}{G D P}=\frac{E_{T}}{G D P} \cdot \frac{E_{F F}}{E_{T}}
$$

This equation states that the fossil fuel intensity of GDP ( $E_{F F} / G D P$ ) is driven by the energy intensity of GDP $\left(E_{T} / G D P\right)$ and the fossil fuel fraction of total energy use $\left(E_{F F} / E_{T}\right)$. We want to know the trends in the right-hand terms in Eq. 3.

Figure 6A shows between-country trends in the energy intensity of GDP vs. service employment share. Figure 6B shows within-country trends for the same relation. A service transition is associated with a decrease in the energy intensity of GDP. This is often touted as evidence for relative dematerialization through services. However, we must account for the type of energy used. Figures $6 \mathrm{C}$ and $6 \mathrm{D}$ show that the fossil fuel energy fraction tends to increase with a service transition. This is evident both between countries (Fig. 6C) and within countries (Fig. 6D). Why does this positive relation exist? Likely because a service transition is a basic part of industrialization. And the latter involves transitioning to fossil fuels (Hall and Klitgaard, 2012; Smil, 2008).

To summarize, the energy intensity of GDP tends to decrease with a service transition. In contrast, the fossil fuel energy fraction tends to increase. These opposing trends explain the between-country relative dematerialization evidence (Fig. 4). Over the long term, the increasing fossil fuel fraction drowns out the decreasing energy intensity of GDP. Since between-country analysis is sensitive to long-term trends, we find that the fossil fuel intensity of GDP increases with a service transition. 
A. Energy Intensity of GDP (Between Countries)

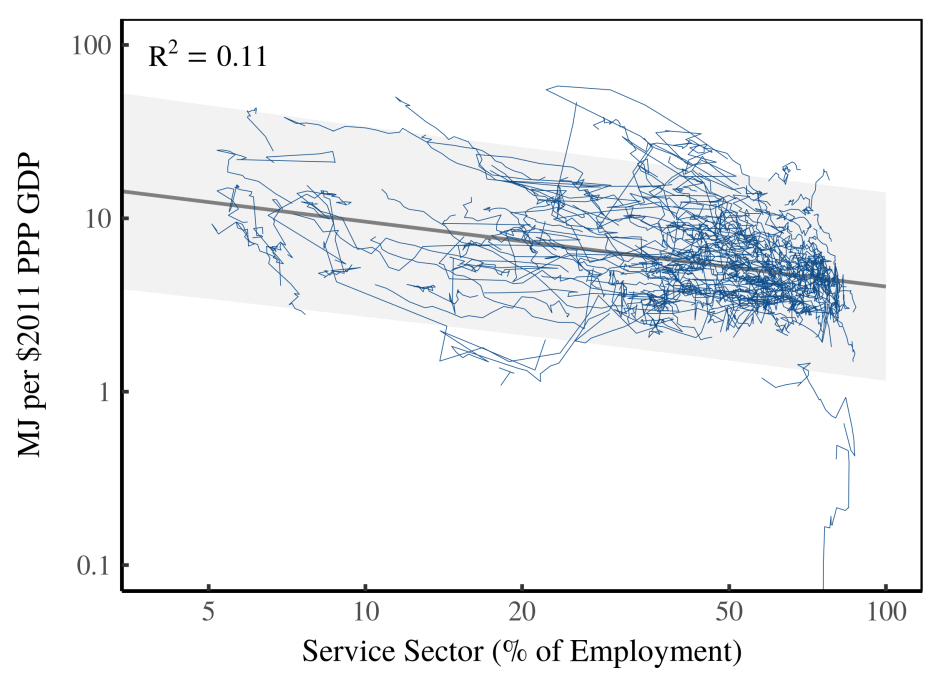

C. Fossil Fuel Energy Fraction (Between Countries)

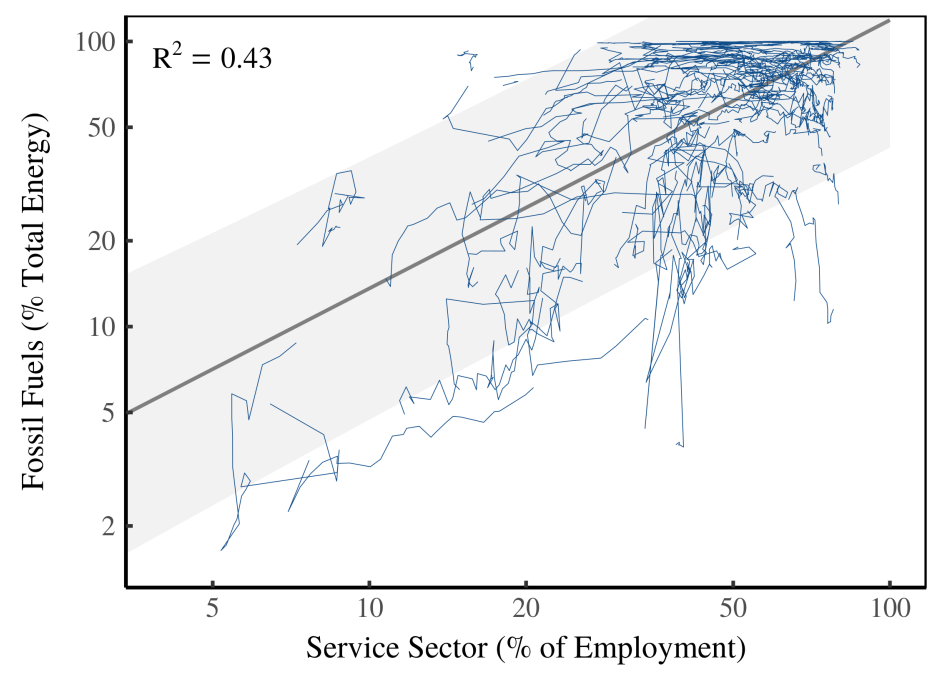

B. Within-Country Scaling of Energy Intensity of GDP vs. Service Employment Share

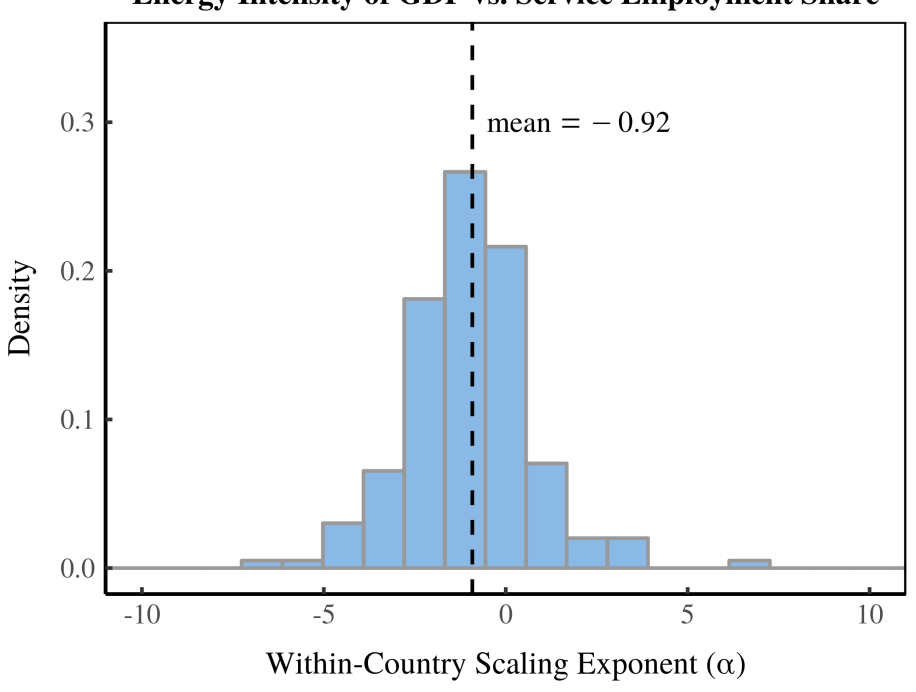

D. Within-Country Scaling of Fossil Fuel Energy Fraction vs. Service Employment Share

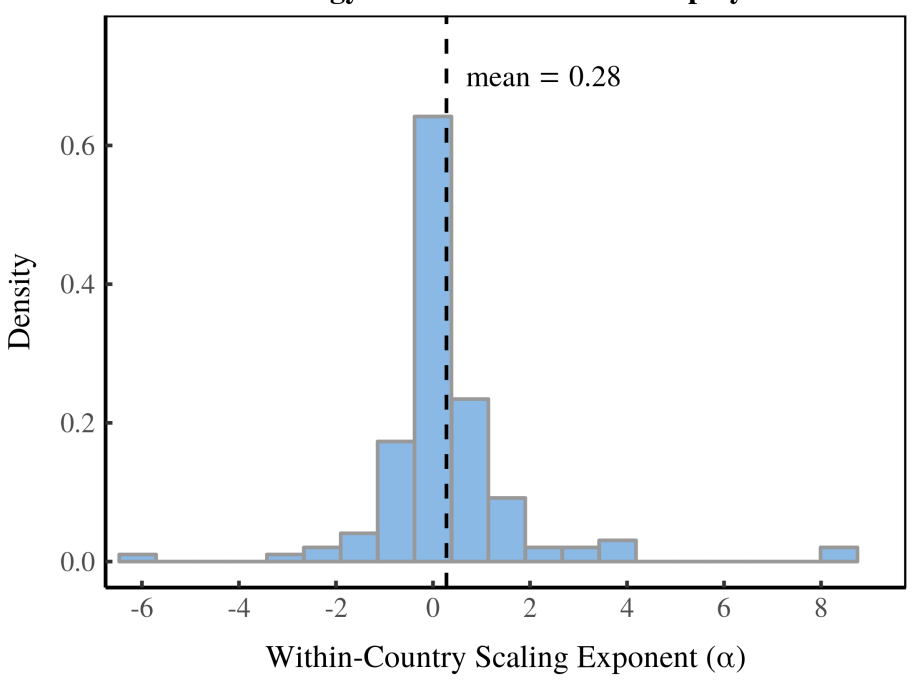

Figure 6: Decomposing Relative Carbon Dematerialization

This figure dissects the relative carbon dematerialization results in Figures 4 and 5 . Panel A shows between-country trends in the energy intensity of GDP vs. service sector employment share. Lines indicate the path through time of individual countries. Panel $\mathrm{B}$ shows the distribution of within-country trends. Results are for log-log regressions on the energy intensity of GDP vs. service sector employment share (see Eqs. 1 and 2). Panel C shows between-country trends for the percentage of energy derived from fossil fuels vs. service sector employment share. Panel D shows the distribution of withincountry trends. Results are for log-log regressions on the fossil fuel energy fraction vs. service sector employment share. Panels $\mathrm{A}$ and $\mathrm{C}$ use log-log scales. $R^{2}$ values are for log-log regressions on national averages. Grey regions indicate the $95 \%$ prediction interval of each regression. All data for comes from the World Bank (Tbl. 2). 
A. Within-Country Scaling of

Fossil Fuel Energy Fraction vs. Service Employment

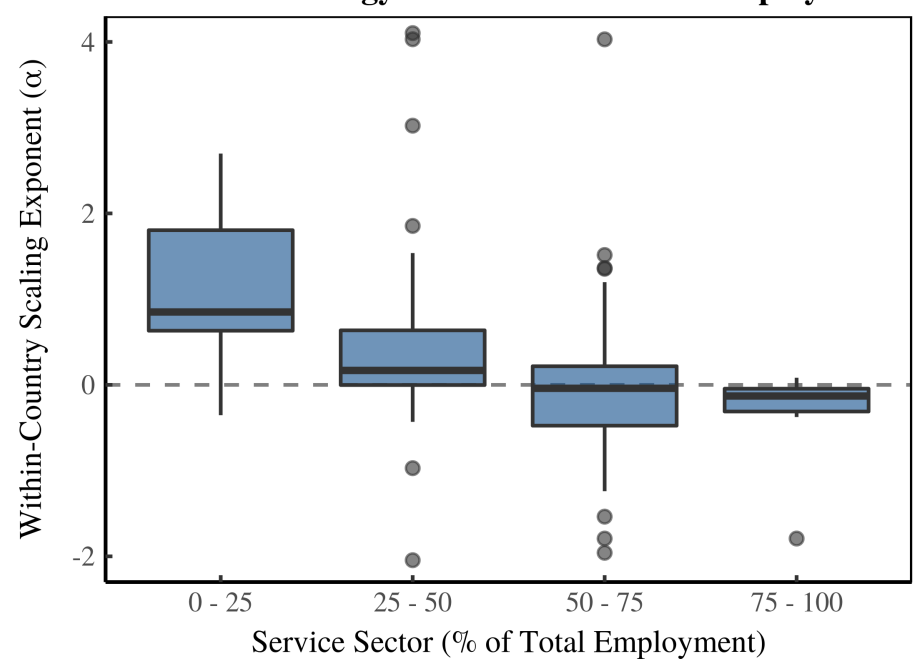

C. Within-Country Scaling of Fossil Fuel Intensity of GDP vs. Service Employment

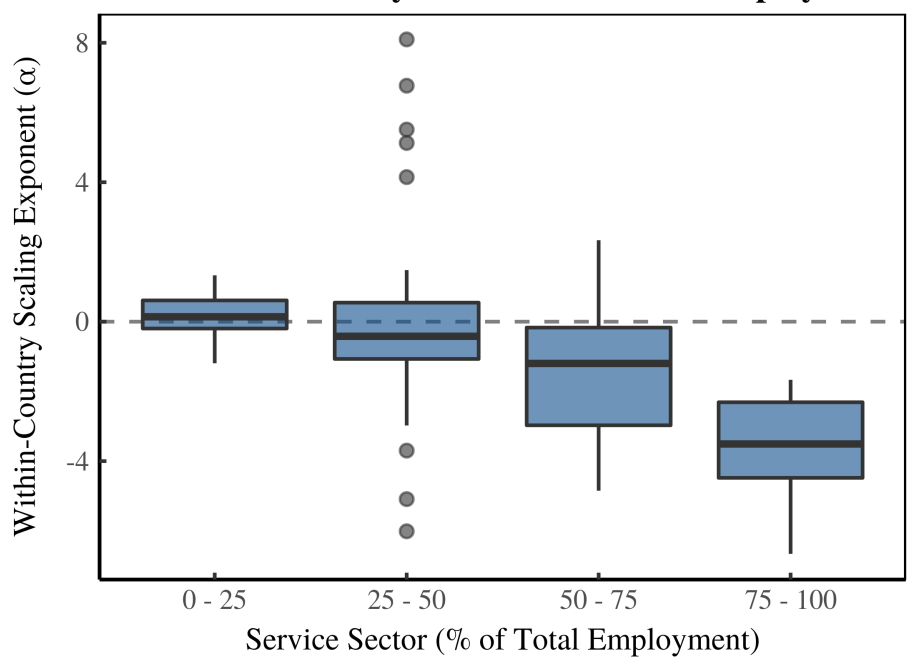

B. US Fossil Fuel Energy Fraction

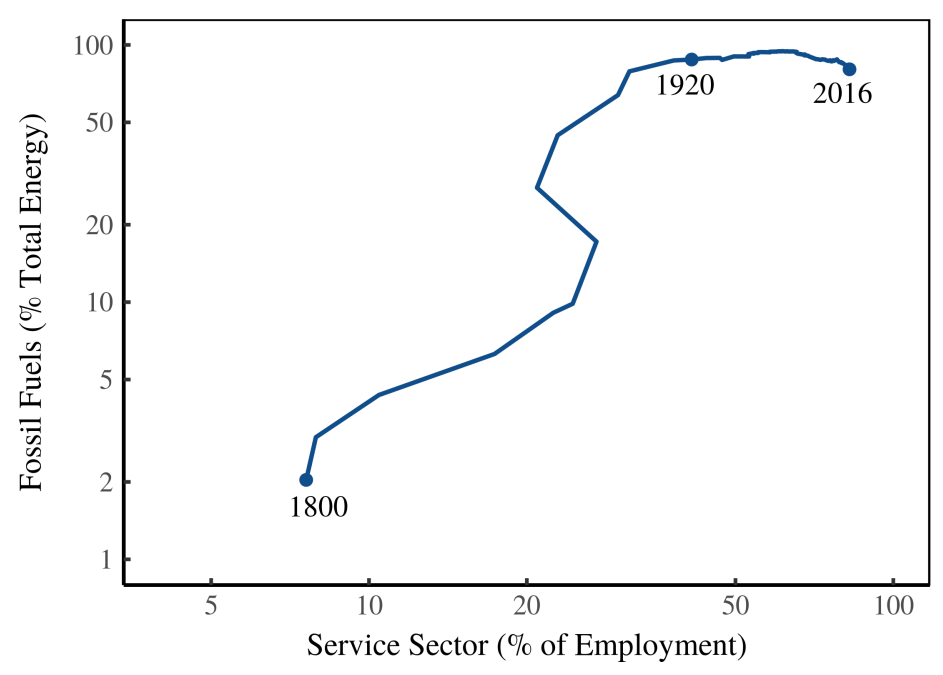

D. Fossil Fuel Intensity of US GDP

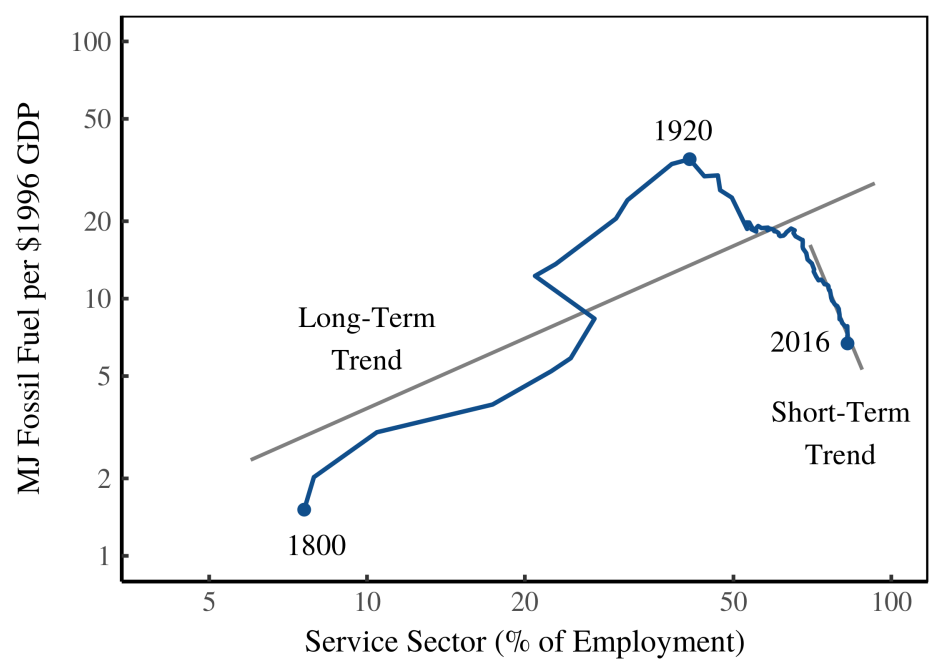

Figure 7: The Plateau of the Fossil Fuel Energy Fraction and the U-Shaped Fossil Fuel Intensity of GDP

This figure shows how the evolution of the fossil fuel energy fraction leads to an inverted U-shaped relation between the fossil fuel intensity of GDP and service sector employment share. Panel A shows within-country trends between the fossil fuel energy fraction and service employment share. Boxplots show the distribution of scaling exponents $(\alpha)$ for $\log$-log regressions (see Eqs. 1 and 2). The distribution of $\alpha$ is disaggregated by country's service sector size. Panel B shows US fossil fuel energy fraction vs. service sector employment share. Panel C shows within-country trends between the fossil fuel intensity of GDP and service sector employment share. Boxplots show the distribution of scaling exponents $(\alpha)$ for log-log regressions. The distribution of $\alpha$ is disaggregated by country's service sector size. Panel D shows the fossil fuel intensity of US GDP relative to service sector employment share. Data for Panels A and C comes from the World Bank (Tbl. 2). For US data sources and methods, see the Appendix. 
When we use within-country data (Fig. 5), we measure short-term trends. This is because the World Bank data covers less than 30 years. Over this period, within-country data indicates that the fossil fuel intensity of GDP decreases with a service transition. This contradictory trend is caused by non-linear behavior in the fossil fuel energy fraction. When countries industrialize, they undergo an energy transition to fossil fuels. But this energy transition eventually reaches fixation - usually when $80 \%$ to $90 \%$ of energy comes from fossil fuels. As a result, the fossil fuel fraction has a non-linear relation with service sector size.

Figures 7A and 7B illustrate this behavior. Figure 7A shows within-country trends between the fossil fuel energy fraction and service employment share. Each boxplot represents the distribution of the scaling exponent ( $\alpha$ ) for a log-log regression (see Eq. 1 and 2). Results are disaggregated by service sector size. We see a clear downward trend as the service sector grows. In countries with a small service sector (less than $50 \%$ of employment), the fossil fuel fraction increases with a service transition. But in countries with a large service sector (greater than $50 \%$ of employment), the fossil fuel fraction remains roughly constant. This behavior is also evident in the US (Fig. 7B). From 1800 to 1920, the fossil fuel fraction increased as the service sector grew. But after 1920, the fossil fuel fraction plateaued - corresponding to a service sector employment share of roughly $40 \%$.

This non-linearity causes an inverted U-shaped relation between the fossil fuel intensity of GDP and service sector size. When the service sector is small, the fossil fuel fraction grows rapidly. This trumps the secular decline in the energy intensity of GDP. The result is an increase in the fossil fuel intensity of GDP with a service transition. But when the fossil fuel transition is complete, the declining energy intensity of GDP dominates the trend. This causes the fossil fuel intensity of GDP to decrease with further service growth.

Figure 7C and 7D illustrate this inverted U-shaped behavior. Figure 7C shows within-country trends between the fossil fuel intensity of GDP and service employment share. Each boxplot represents the distribution of the scaling exponent $(\alpha)$ for a log-log regression (see Eq. 1 and 2). Results are disaggregated by service sector size. The relation is positive when the service sector is small. This means a service transition leads to greater fossil fuel intensity of GDP. But the relation becomes negative when the service sector is large. This means a continued service transition leads to lesser fossil fuel intensity of GDP

If we had access to long-term trends for each individual country, they would likely look like those of the United States (Fig. 7B). From 1800 to 1920, the fossil fuel intensity of US GDP increased as the service sector grew. But after 
1920, the fossil fuel intensity of US GDP decreased as the service sector grew. The change in behavior corresponds to the plateau of fossil fuel use (Fig. 7B).

Importantly, the downward part of the $\mathrm{U}$ does not fully reverse the upward part. This means that the long-term US trend is positive, even though the recent trend is negative. This explains our conflicting results in Figures 4 and 5. The between-country analysis captures snapshots of countries along the long-term upward trend. The within-country analysis captures recent trends. Evidently most countries are now in the downward part of the U. However, this decrease in the fossil fuel intensity of GDP has not undone the large increases of the past.

\subsection{Judging the Success of Relative Carbon Dematerialization}

The U shape in the fossil fuel intensity of GDP complicates the judgment of relative dematerialization through services. Our verdict depends on our choice of time scale. Is a services transition a long-term phenomena? If so, then relative carbon dematerialization through services is a failure. Or is a service transition a recent phenomena? If so, relative carbon dematerialization has some success.

Trends in the United States suggest that a service transition is a long-term process. (Fig. 8A). The employment share of the US service sector has grown continuously for over 200 years (other than a dip during the Civil War). What stands out in recent US history is not the growth of services, but the decline in industrial employment from 1970 onward. This is what many environmental economists think of as the 'service transition' - the replacement of industrial activity with service activity. The problem is that this deindustrialization trend is likely an artifact of global trade. The US is now a massive net importer of goods (Gierlinger and Krausmann, 2012). This means that industrial employment is far smaller than it would be if all goods production happened domestically.

The only way to be sure that trade effects are not involved is to look at the world economy - the only closed economy on Earth. On the world scale, there is no hint of deindustrialization (Fig. 8B). Instead, the trends mirror the longterm behavior in the US. Agriculture employment is declining, service sector employment is increasing, and industrial employment is roughly constant. This suggests that a service transition is a long-term process in which service employment replaces agricultural employment.

Thus, to evaluate the 'dematerialization through services' hypothesis, we must give the most weight to long-term trends. On this front, the evidence is clear. Over the long term, a service transition does not lead to relative carbon dematerialization. And even if we are interested in short-term trends, we still 
A. United States

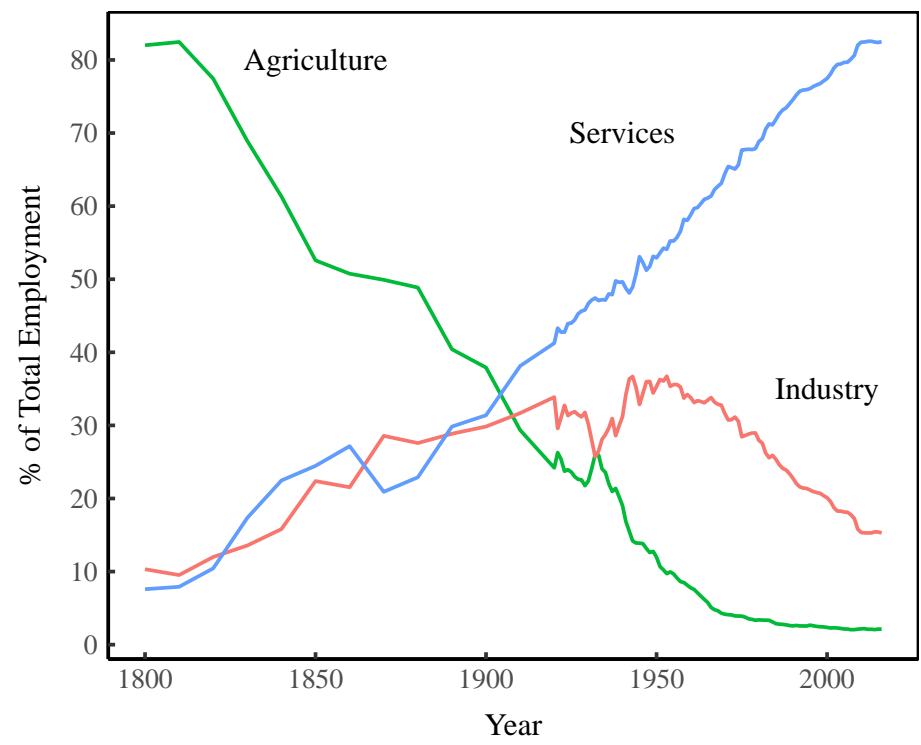

B. World

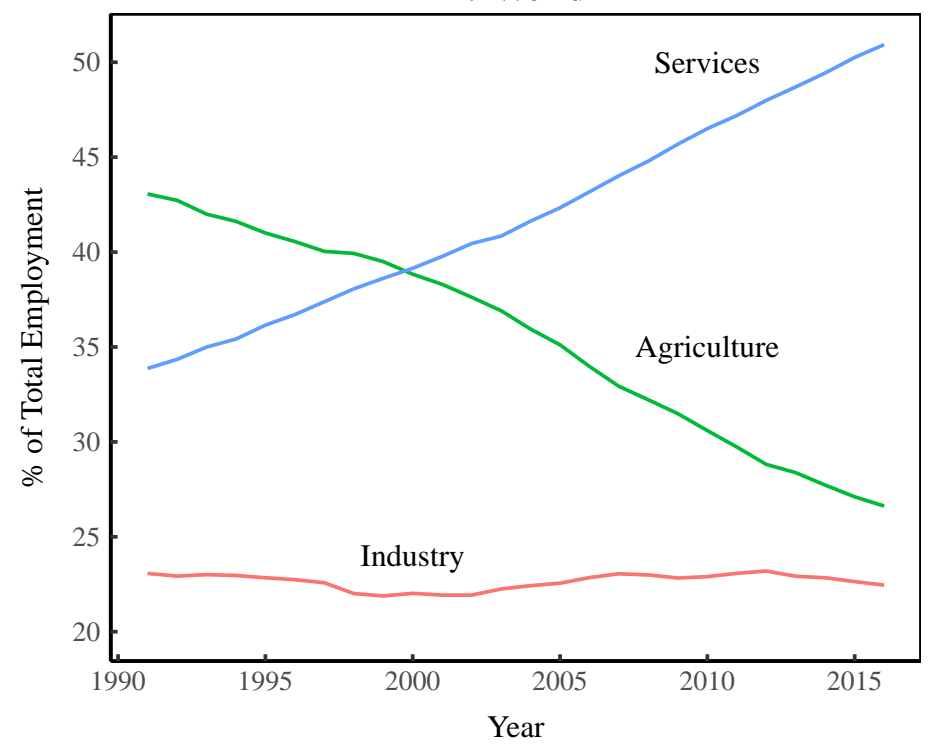

Figure 8: Labor Structure Changes in the United States and the World

This figure shows historical changes in the three-sector labor structure of the United States economy (Panel A) and the world economy (Panel B). For US data sources and methods, see the Appendix. World data comes from the World Bank (Tbl. 2). World sector composition is calculated using national averages, weighted by national labor force size.

have a problem. Relative carbon dematerialization has nothing to do with sustainability. Instead, it indicates how societies value economic activity in relation to carbon emissions. This valuation is an interesting sociological process that is worth studying. But it does not measure biophysical sustainability.

\subsection{The Failure of Absolute Carbon Dematerialization}

The failure of absolute carbon dematerialization through services is due to two factors. First, the fossil fuel energy fraction increases with service sector size (Figs. 6A and 6B). Second, energy use per capita tends to increase with a service transition (Fig. 9). Given these two trends, it is unsurprising that absolute dematerialization through services fails.

What is surprising is the pervasiveness of the energy-services relation. A link between energy use and service employment is evident at many levels of analysis. It is evident for the world as a whole (Fig. 9A). This is important, because the world is a closed system, so we can be sure that trade effects are not at play 
(i.e. offshoring pollution-intensive industry). A trend between energy use and service sector employment is evident between countries (Fig. 9B) and within countries (Fig. 9C). It is also evident over two centuries of US history (Fig. 9D).

An energy-service trend is also evident within US industry. Figure 9E plots energy use per worker in US industry against the employment share of nonproduction workers in industry. Non-production workers are employed by goodsproducing firms, but not directly involved with production (BLS, 1957). These workers do service-type activity within industry. Evidently this service-type activity tends to grow as industrial energy use increases.

To summarize, an energy-services relation is evident at the global, international, national, and sectoral level. Moreover, this energy comes mostly from fossil fuels. As a result, a service transition is associated with greater carbon emissions.

\subsection{Why is a Service Transition Associated With Greater Energy Use?}

The increase of energy use with a service transition seems counter-intuitive. Compared to industry, the service sector uses far less direct energy per worker (Fig. 1). Yet the growth of service employment is strongly associated with the growth of energy use per capita. How can this be?

Jesper Jespersen points out a flaw in the 'dematerialization through services' reasoning. It assumes that a society can replace industrial activity with service activity, while leaving the structure of both sectors unchanged. But this is not what happens. Jespersen elaborates:

A significant and perhaps fundamental weakness of [the 'dematerialization through services' proposal] is that in the real economy (especially within the private sector) agriculture, manufacturing and services cannot be treated separately. Goods cannot be produced, sold and consumed without involving services related to business, finance, transport, the wholesale and retail trade, communication, waste processing and so on. In many respects these activities are complements rather than substitutes. The point is that it is not possible just to switch between the manufacturing and service sectors because the indirect impact of changes in the altered manufacturing sector on the service sector is quite considerable. (Jespersen, 1999)

In reality, a service transition is associated with a host of complex social changes. Most importantly, the growth of services is related to economic growth. This is an old idea, not a new discovery. More than 70 years ago Colin Clark argued that "the most important concomitant of economic progress" was "the 
A. World as Whole

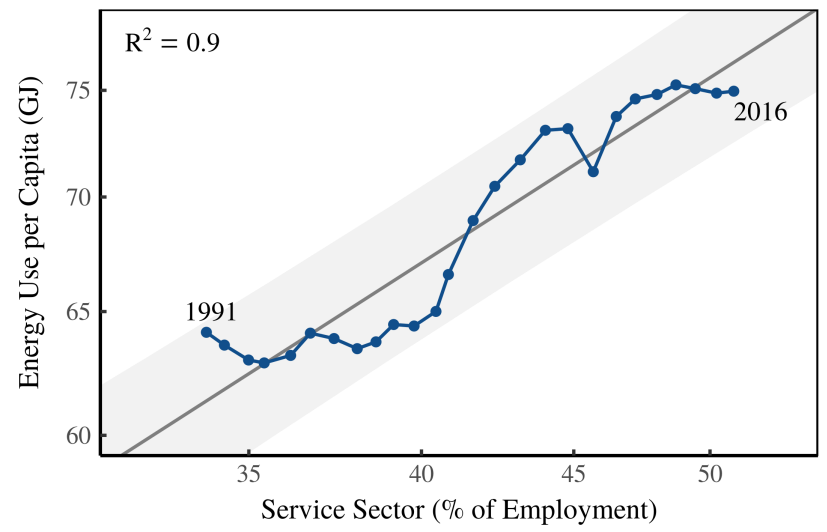

C. Within-Country Scaling

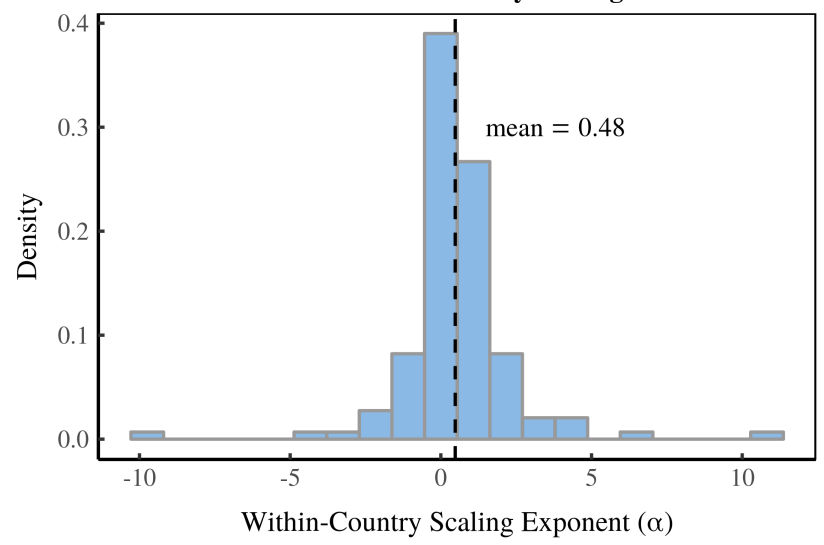

E. US Industry

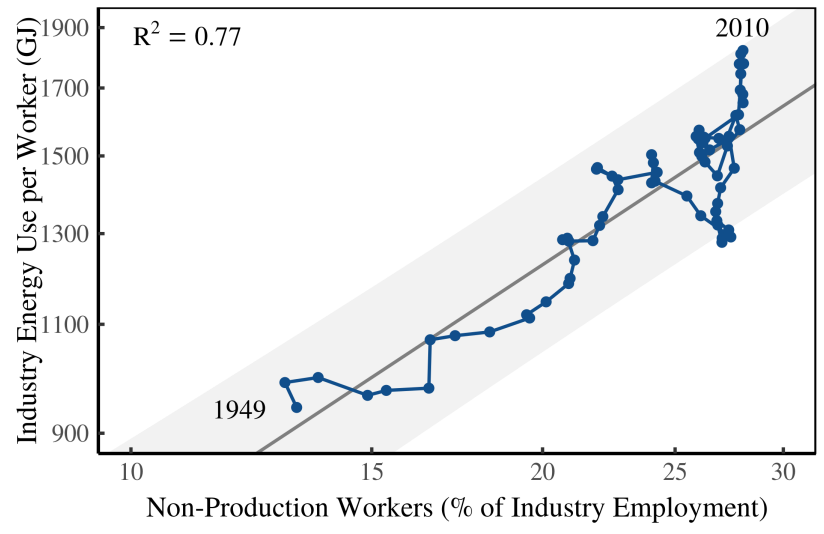

B. Between Countries

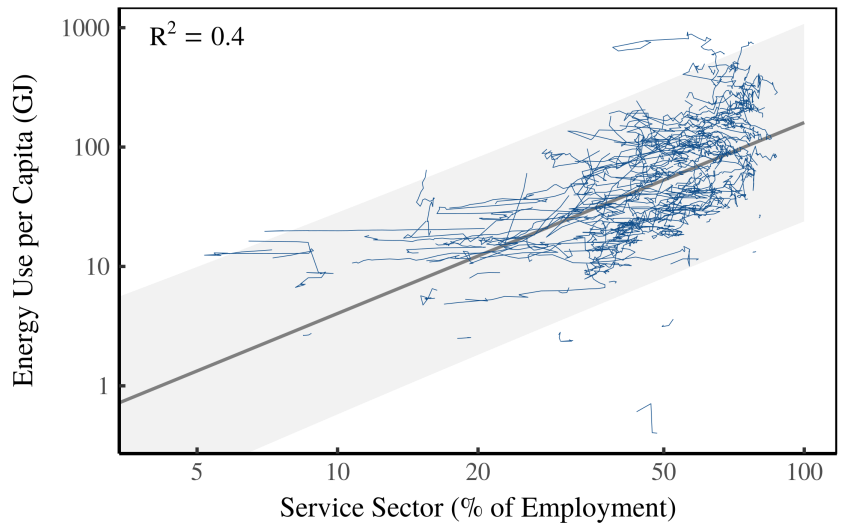

D. United States

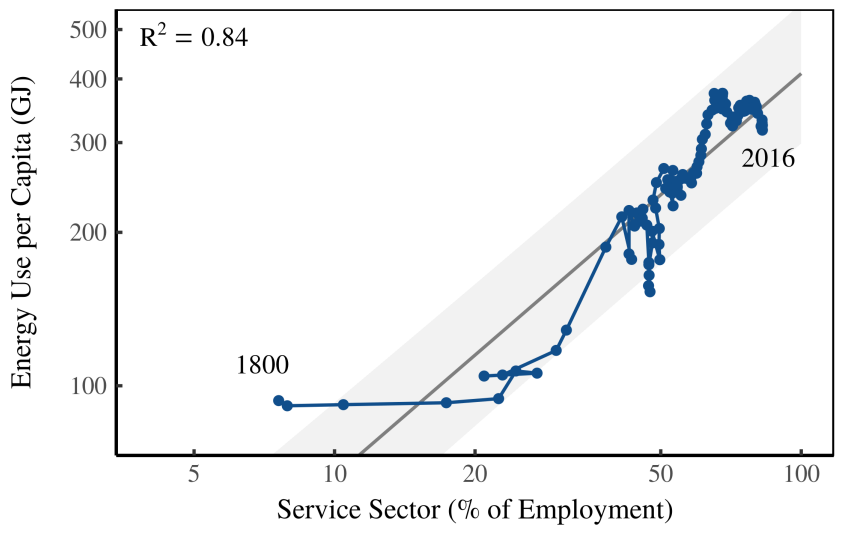

Figure 9: Energy Use per Capita vs. Service Sector Employment

This figure plots energy use per capita against service sector employment share. Panel A shows the world as a whole. World service employment share is the average of all national data, weighted by national labor force size. Panel B shows the trend between countries. Each line represents a country's path through time. Panel C shows the distribution of within-country trends between energy use per capita and service employment share. Results are for the scaling exponent $\alpha$ of log-log regressions (see Eqs. 1 and 2). Panel D plots two centuries of data from the United States. Panel E plots labor-structure change inside US industry. The growth of energy use per worker in US industry is strongly related to the growth of non-production workers in industry (i.e. service-type workers). $R^{2}$ values are for log-log regressions. Grey regions indicate the $95 \%$ prediction interval of each regression. All panels (except Panel C) use log-log scales. Data for Panels A, B and C come from the World Bank (Tbl. 2), with the exception of world energy use, which comes from the BP Statistical Review 2017. US data sources are discussed in the Appendix. 
movement of working population from agriculture to manufacture, and from manufacture to commerce and services" (Clark, 1940). Proponents of 'dematerialization through services' have forgotten this idea. If a service transition is a key part of economic growth, it is easy to see why it fails to reduce emissions. Economic growth is overwhelmingly associated with increases in energy use (Brown et al, 2011, 2014).

To understand the link between economic growth, energy, and sectoral change, it is helpful to focus on labor productivity. Economists are nearly unanimous that economic growth involves increasing worker productivity. But what is often undiscussed is that increasing productivity generally requires greater energy use. Why? Productivity growth is typically achieved by augmenting human labor with machines. And these machines require energy to function. The laws of thermodynamics forbid otherwise. Thus mechanization requires ramping up the energy used by machines. Not suprisingly, there is a strong relation between labor productivity and energy use (Cleveland et al, 1984; Hall et al, 1986; Fix, 2015).

But how does the growth of productivity relate to a service transition? One possibility is that the service sector grows to consume the surplus produced in other sectors. Giampietro et al. credit George Zipf (1941) for first emphasizing consumption capacity:

Zipf proposed a basic principle of socio-economic development: if an economy wants to be able to produce more, it has to invest more in consuming. This principle implies that socio-economic development must be based on achieving an internal balance between parallel investments both of human activity and of energy over the two compartments of production and consumption ...

(Giampietro et al, 2012)

Another possibility is that the service sector provides facilitation activity to other sectors (North, 1990). Many services (such as accounting, logistics, education, etc.) are essential to goods production. It seems plausible that the demand for these services grows with energy use. Indeed, the evidence in Figure 9D hints that this is the case. As energy use per worker in US industry increases, so does the share of service-type activity (measured as the employment share of non-production workers).

Why is there a link between energy use and facilitation activity? A plausible reason is that increasing energy use requires more complex technology (Fix, 2017). As an example, consider the difference between subsistence and industrial agriculture. Subsistence farmers produce most of their own tools. Industrial farmers do not. Think of the large machines used by industrial farmers. Now pic- 
A. Between-Countries

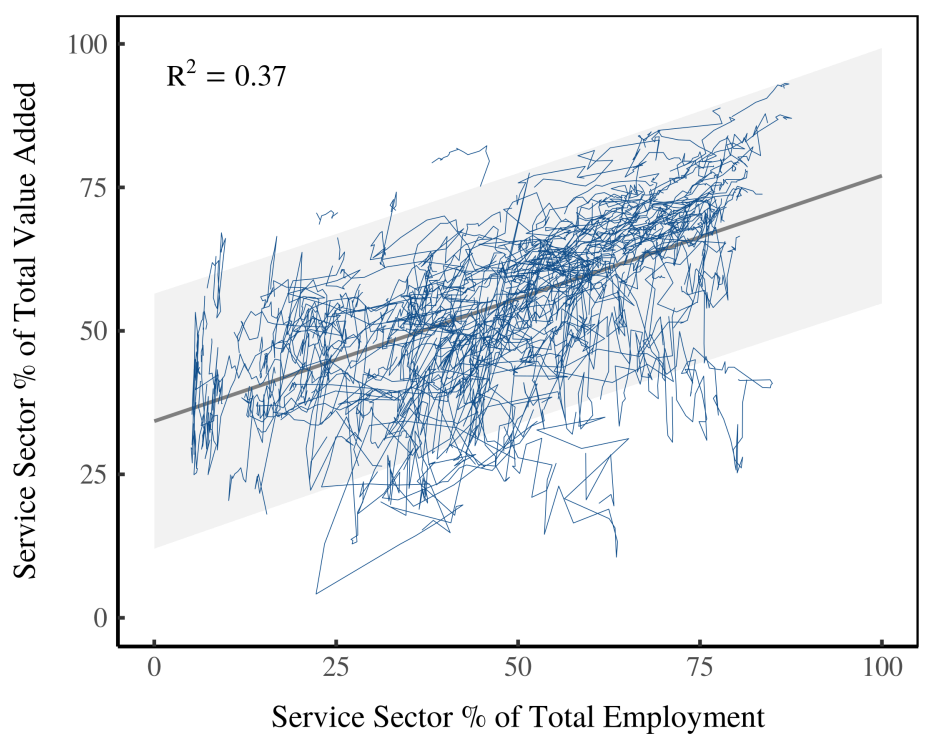

B. Within-Countries

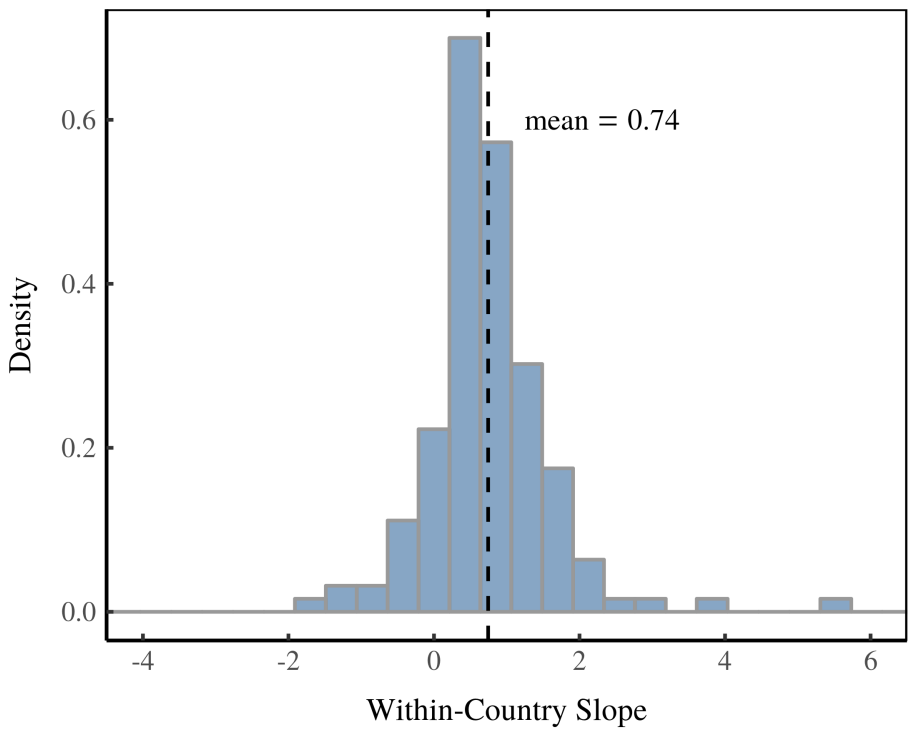

\section{Figure 10: Service Sector Share of Value Added vs. Share of Employment}

Panel A plots national data for service value-added share against service employment share. Lines represent the path through time of countries. The $R^{2}$ value is for a linear regression conducted on national averages. The shaded region indicates the $95 \%$ prediction interval of the regression. Panel B shows the distribution of within-country trends. The 'within-country slope' measures the average change in service share of value added for a unit change in service share of employment. All data comes from the World Bank (Tbl. 2).

ture the services needed to produce and maintain these machines. This includes the engineers who design the machines, the administrators who coordinate production, the educators who train the skilled workforce, and so on. It may be a general rule that facilitation activity tends to grow as technology becomes more complex. This is consistent with the tendency for social complexity to increase with economic development (Carneiro, 1967; Naroll, 1956; Zipf, 1949).

I have focused on the movement of employment between sectors because it makes the flaws in the 'dematerialization through services' hypothesis easiest to spot. But what if a country increases the service sector's share of value added without shifting employment? While this may be possible in principle, the evidence suggests it is hard to do in practice. National variation in service sector employment share accounts for about $37 \%$ of the variation in service sector value-added share (Fig. 10A). Within countries, a 1\% increase in service employment share leads to an average increase of $0.75 \%$ in service value-added 
share (Fig. 10B). This is not hard to understand. Most services are labor intensive (think health care and education) and increasing labor productivity is difficult (Baumol, 1967).

\section{Conclusions}

In 1972, the Club of Rome released its famous report The Limits to Growth (Meadows, 1972). Since then, economists have debated whether economic growth can decouple from environmental impact. Proponents of the 'environmental Kuznets curve' argue that decoupling is possible (Grossman and Krueger, 1994; Panayotou, 1993; Shafik and Bandyopadhyay, 1992). The idea is that environmental impact first rises and then falls with economic growth. The transition to services provides a plausible mechanism for this decoupling. Panayotou et al (2000) propose that "economic growth brings about structural change that shifts the center of gravity of the economy from low-polluting agriculture to high-polluting industry and eventually back to low polluting services".

The problem with this hypothesis is that it neglects the complex social changes that come with a service transition. As Colin Clark (1940) observed long ago, sectoral change seems to be a key part of economic growth. And economic growth is strongly associated with the growth of fossil fuel energy use (Brown et al, 2011, 2014). When framed this way, it is not surprising that the 'dematerialization through services' hypothesis fails. I find no evidence that a service transition reduces carbon emissions. Instead, it is associated with the growth of per capita emissions.

What are the implications for policy makers? It seems that a service transition does not 'automatically' lead to decreased environmental impact. This implies that purposeful policy intervention is required. It is obviously important to decarbonize energy sources by investing in renewable energy. But it is unclear how this relates to sectoral change (if it relates at all). Future research may make this clearer. But for now, we can draw a simple conclusion. The evidence indicates that 'dematerialization through services' is not a valid policy for reducing carbon emissions.

\section{Acknowledgements}

I would like to thank the anonymous reviewers for comments that have improved this paper. I also thank Charles Hall and Kent Klitgaard for helpful comments on earlier versions of this research. 


\section{Conflicts of Interest}

The author acknowledges no conflicts of interest. 


\section{Appendix}

This paper has a supplementary website containing raw and final data as well as code for all analysis:

$$
\text { https://osf.io/93fpn/ }
$$

\section{A Sources and Methods}

US energy intensity by sector (Fig. 1): Sources and methods for calculating US sectoral energy use, employment, and value added are shown in Table 7. Except for energy consumption in the US service sector, all data is taken as given from the official data. The US Energy Information Agency (EIA) uses energy consumption categories that differ from the standard national income and product accounts categories used by the Bureau of Economic Analysis (BEA). The EIA energy data uses four categories: Industrial use, Commercial use, Transport use, and Residential use.

To allocate transport energy to the service sector, I apply the method developed by Giampietro, Mayumi, and Sorman (2012; 2013). I define service sector energy use $\left(E_{\text {Service }}\right)$ as commercial energy $\left(E_{\text {Commercial }}\right)$ plus work-related transport energy ( $\left.E_{\text {Work-Related Transport }}\right)$.

$$
E_{\text {Service }}=E_{\text {Commercial }}+E_{\text {Work-Related Transport }}
$$

work-related transport energy is calculated by subtracting non-work related energy from transport energy. Non-work related transport energy is defined as all transport energy minus light-duty vehicle energy consumed for non-work related trips.

$$
E_{\text {Work-Related Transport }}=E_{\text {Transport }}-E_{\text {Light-Duty }} \cdot \frac{V M T_{\text {Non-Work }}}{V M T_{\text {Total }}}
$$

Here VMT stands for vehicle-miles-traveled. Data for US light-duty vehicle energy use comes from various EIA Annual Energy Outlooks from 2000 to 2018. Vehicle-miles-traveled data comes from the National Household Travel Survey 2009 and 2017. 
Table 7: Sources and Methods for US Sectoral Energy Use, Employment, and Value Added

\begin{tabular}{|c|c|c|c|}
\hline & Industry & Services & Source \\
\hline Energy Use & Industry Energy & Commercial Energy + Work-Related Transport Energy & $\begin{array}{l}\text { EIA Annual Energy Review Table } 2.1 \\
\text { Various Annual Energy Outlooks } \\
\text { National Household Travel Survey } 2009 \& 2017\end{array}$ \\
\hline Employment & $\begin{array}{l}\text { Mining } \\
\text { Utilities } \\
\text { Construction } \\
\text { Manufacturing }\end{array}$ & $\begin{array}{l}\text { Wholesale Trade } \\
\text { Retail Trade } \\
\text { Transportation and Warehousing } \\
\text { Information } \\
\text { Finance and Insurance } \\
\text { Real Estate and Rental and Leasing } \\
\text { Professional, Scientific, and Technical Services } \\
\text { Management of Companies } \\
\text { Administrative and Waste Management Services } \\
\text { Education Services } \\
\text { Health Care and Social Assistance } \\
\text { Arts, Entertainment, Recreation } \\
\text { Accommodation and food services } \\
\text { Other Services } \\
\text { Government }\end{array}$ & $\begin{array}{l}\text { BEA Table 6.8D } \\
\text { Persons Engaged in Production }\end{array}$ \\
\hline Value Added & $\begin{array}{l}\text { Mining } \\
\text { Utilities } \\
\text { Construction } \\
\text { Manufacturing }\end{array}$ & $\begin{array}{l}\text { Wholesale Trade } \\
\text { Retail Trade } \\
\text { Transportation and Warehousing } \\
\text { Information } \\
\text { Finance, Insurance, Real Estate, Rental, Leasing } \\
\text { Professional and Business Services } \\
\text { Education Services, Health Care, Social Assistance } \\
\text { Arts, Entertainment, Recreation, Accommodation, and Food Services } \\
\text { Other Services } \\
\text { Government }\end{array}$ & BEA Real Value Added by Industry \\
\hline
\end{tabular}

Notes: EIA = Energy Information Agency, BEA = US Bureau of Economic Analysis 


\section{US sectoral composition and historical energy use (Figs. 7B and D, 8A and} 9D). US sectoral labor composition sources are shown in Table 8. Because the series are not mutually consistent, there is inherent ambiguity in the historical data. To quantify this ambiguity, I use a Monte Carlo technique to randomly splice together the series in different ways. I then use the median of this spliced data.

US historical energy and fossil fuel use data (1800-1945) comes from EIA Annual Review 2009, Table E1. Fossil fuel energy use data begins in 1850. I use an exponential regression to extrapolate trends back to 1800. US energy data from 1949 onward comes from the EIA Annual Energy Review, Table 1.3.

Table 8: Sources for US Sectoral Labor Composition

\begin{tabular}{llll}
\hline Years & Sector & Source & Description \\
\hline $1800-1920$ & All & HSUS Table BA814-830 & The labor force, by industry: 1800-1960 \\
$1920-1929$ & Agriculture & HSUS Table BA470-477 & $\begin{array}{l}\text { Labor force, employment, and unemploy- } \\
\text { ment: 1890-1990 }\end{array}$ \\
& & & $\begin{array}{l}\text { Employees on non-agricultural payrolls, } \\
\text { by industry: 1919-1999 }\end{array}$ \\
$1920-1929$ & Non-Agriculture & HSUS Table BA840-848 & Persons Engaged in Production \\
$1929-1948$ & All & BEA Table 6.8A & $\begin{array}{l}\text { Persons Engaged in Production } \\
1948-1987\end{array}$ \\
All & All & BEA Table 6.8B & $\begin{array}{l}\text { Persons Engaged in Production } \\
\text { BEA Table 6.8C }\end{array}$ \\
$1987-2000-2016$ & All & BEA Table 6.8D & Persons Engaged in Production \\
\hline
\end{tabular}

HSUS $=$ Historical Statistics of the United States; BEA = Bureau of Economic Analysis

US industry energy use and non-production employment (Fig. 9E): US industry energy data comes from EIA Annual Energy Review Table 2.1. Industry employment comes from BEA Tables 6.8A-D (persons engaged in production). I calculate employment of non-production workers in industry is using Bureau of Labor Statistics series CES0600000006 (Production and non-supervisory employees, goods-producing) and series CES0600000001 (All employees, goodsproducing). I define non-production workers as the difference between total employment and production employment. 


\section{References}

Alcott B (2005) Jevons' paradox. Ecological economics 54(1):9-21

Baumol WJ (1967) Macroeconomics of unbalanced growth: the anatomy of urban crisis. The American Economic Review 57(3):415-426

BLS (1957) Nonproduction Workers in Factories, 1919-56. Monthly Labor Review 80(4):435-440

Brown JH, Burnside WR, Davidson AD, DeLong JP, Dunn WC, Hamilton MJ, Mercado-Silva N, Nekola JC, Okie JG, Woodruff WH, Zuo W (2011) Energetic Limits to Economic Growth. BioScience 61(1):19-26, DOI 10.1525/bio.2011. 61.1 .7

Brown JH, Burger JR, Burnside WR, Chang M, Davidson AD, Fristoe TS, Hamilton MJ, Hammond ST, Kodric-Brown A, Mercado-Silva N, Nekola JC, Okie JG (2014) Macroecology meets macroeconomics: Resource scarcity and global sustainability. Ecological Engineering 65:24-32, DOI 10.1016/j. ecoleng.2013.07.071

Carneiro RL (1967) On the relationship between size of population and complexity of social organization. Southwestern Journal of Anthropology 23(3):234243

Clark C (1940) The Conditions of Economic Progress. Macmillan \& Company, London

Cleveland C, Costanza R, Hall C, Kaufmann R (1984) Energy and the US economy: a biophysical perspective. Science 225(4665):890-897

Cooper T (1999) Creating an economic infrastructure for sustainable product design. Journal of sustainable product design pp 7-17

Daly H (2013) A further critique of growth economics. Ecological economics $88: 20-24$

Davis SJ, Caldeira K (2010) Consumption-based accounting of CO2 emissions. Proceedings of the National Academy of Sciences 107(12):5687-5692

Day JW, Moerschbaecher M, Pimentel D, Hall C, Yáñez-Arancibia A (2014) Sustainability and place: How emerging mega-trends of the 21st century will affect humans and nature at the landscape level. Ecological Engineering 65:3348 
Djellal F, Gallouj F (2016) Service innovation for sustainability: paths for greening through service innovation. In: Service innovation, Springer, pp 187-215

Ehrlich PR, Holdren JP (1971) Impact of population growth. Science 171(3977):1212-1217

Ellger C, Scheiner J (1997) After industrial society: service society as clean society? Environmental consequences of increasing service interaction. Service Industries Journal 17(4):564-579

Fix B (2015) Rethinking Economic Growth Theory from a Biophysical Perspective. Springer, New York

Fix B (2017) Energy and Institution Size. PLOS ONE 12(2):e0171,823, DOI doi:10.1371/journal.pone.0171823

Fix B (2019) The Aggregation Problem: Implications for Ecological and Biophysical Economics. BioPhysical Economics and Resource Quality 4(1):1

Giampietro M, Mayumi K, Sorman A (2012) The Metabolic Pattern of Societies: Where Economists Fall Short. Routledge, New York

Giampietro M, Mayumi K, Sorman A (2013) Energy Analysis for a Sustainable Future: Multi-Scale Integrated Analysis of Societal and Ecosystem Metabolism. Routledge, New York

Gierlinger S, Krausmann F (2012) The Physical Economy of the United States of America. Journal of Industrial Ecology 16(3):365-377

Grossman G, Krueger A (1994) Economic growth and the environment. National Bureau of Economic Research Cambridge, Mass., USA

Hall C, Klitgaard K (2012) Energy and the Wealth of Nations: Understanding the Biophysical Economy. Springer, New York

Hall CAS, Cleveland CJ, Kaufmann RK (1986) Energy and resource quality: the ecology of the economic process. Wiley Interscience, New York

Hawken P (2000) Natural capitalism : creating the next industrial revolution. Little, Boston

Heiskanen E, Jalas M (2000) Dematerialization through services-A review and evaluation of the debate. Tech. rep., Finnish Ministry of the Environment, Helsinki 
Heiskanen E, Halme M, Jalas M, Kärnä A, Lovio R (2001) Dematerialization: the potential of ICT and services. Tech. rep., Finnish Ministry of the Environment, Helsinki

Henriques ST, Kander A (2010) The modest environmental relief resulting from the transition to a service economy. Ecological Economics 70(2):271-282

Herman R, Ardekani SA, Ausubel JH (1990) Dematerialization. Technological forecasting and social change 38(4):333-347

Hinterberger F, Schmidt-Bleek F (1999) Dematerialization, MIPS and Factor 10 Physical sustainability indicators as a social device. Ecological Economics 29(1):53-56

Jackson T (1996) Material Concerns: Pollution, Profit, and Quality of life. Routledge, New York

Jackson T (2009) Prosperity without growth: Economics for a finite planet. Routledge

Jespersen J (1999) Reconciling environment and employment by switching from goods to services? A review of Danish experience. European Environment 9(1):17-23

Jevons WS (1906) The coal question: an inquiry concerning the progress of the nation, and the probable exhaustion of our coal-mines. The Macmillan Company

Kahn H (1979) World economic development 1979 and beyond

Kander A (2005) Baumol's disease and dematerialization of the economy. Ecological economics 55(1):119-130

Knight KW, Schor JB (2014) Economic growth and climate change: a crossnational analysis of territorial and consumption-based carbon emissions in high-income countries. Sustainability 6(6):3722-3731

Lawn PA (2001) Goods and services and the dematerialisation fallacy: implications for sustainable development indicators and policy. International Journal of Services Technology and Management 2(3-4):363-376

Lovins AB, Lovins LH, Hawken P (1999) A road map for natural capitalism

Meadows DH (1972) The limits to growth : a report for the Club of Rome's project on the predicament of mankind. New American Library, New York 
Naroll R (1956) A preliminary index of social development. American Anthropologist 58(4):687-715

Nitzan J (1992) Inflation as restructuring. A theoretical and empirical account of the US experience. PhD thesis, McGill University

Nitzan J, Bichler S (2009) Capital as Power: A Study of Order and Creorder. Routledge, New York

North DC (1990) Institutions, Institutional Change and Economic Performance. Cambridge University Press, New York

OECD (2000) The Service Economy. Tech. rep., ORGANISATION FOR ECONOMIC CO-OPERATION AND DEVELOPMENT, Paris

Panayotou T (1993) Empirical tests and policy analysis of environmental degradation at different stages of economic development. ILO, Technology and Employment Programme, Geneva

Panayotou T, Peterson A, Sachs JD (2000) Is the environmental Kuznets curve driven by structural change? What extended time series may imply for developing countries. CAER II Discussion Paper No. 80

Polimeni J, Mayumi K, Giampietro M, Alcott B (2012) The Jevons paradox and the myth of resource efficiency improvements. Routledge, London

Romm J (2002) The internet and the new energy economy. Resources, conservation and recycling 36(3):197-210

Romm J, Rosenfeld A, Herrmann S (1999) The internet economy and global warming. Tech. rep., The Center for Energy and Climate Solutions

Shafik N, Bandyopadhyay S (1992) Economic growth and environmental quality: time series and cross-country evidence. Policy Research Working Paper Series

Smil V (2008) Energy in nature and society: general energetics of complex systems. MIT press, Cambridge, MA

Stahel WR (1997) The service economy: 'wealth without resource consumption'? Philosophical Transactions of the Royal Society of London Series A: Mathematical, Physical and Engineering Sciences 355(1728):1309-1319 
Stern DI, Common MS, Barbier EB (1996) Economic growth and environmental degradation: The environmental Kuznets curve and sustainable development. World Development 24(7):1151-1160, DOI 10.1016/0305-750X(96) 00032-0

Victor P (2010) Questioning economic growth. Nature 468(7322):370-371, DOI 10.1038/468370a

White AL, Stoughton M, Feng L (1999) Servicizing: the quiet transition to extended product responsibility. Tellus Institute, Boston 97

Zipf GK (1941) National Unity and Disunity. Principia Press, Bloomington, Indiana

Zipf GK (1949) Human behavior and the principle of least effort. AddisonWesley, Cambridge 